\title{
Epithelial-Mesenchymal Plasticity in Circulating Tumor Cells, the Precursors of Metastasis
}

\author{
Risa Burr, Christine Gilles, Erik W. Thompson, \\ and Shyamala Maheswaran
}

\section{Abstract}

Circulating tumor cells offer an unprecedented window into the metastatic cascade, and to some extent can be considered as intermediates in the process of metastasis. They exhibit dynamic oscillations in epithelial to mesenchymal plasticity and provide important opportunities for prognosis, therapy response monitoring, and targeting of metastatic disease. In this manuscript, we review the involvement of epithelial-mesenchymal plasticity in the early steps of metastasis and what we have learned about its

R. Burr

Massachusetts General Hospital Cancer Center,

Harvard Medical School, Charlestown, MA, USA

C. Gilles

Laboratory of Tumor and Development Biology, GIGA-Cancer, University of Liège, Liège, Belgium

E. W. Thompson

Institute of Health and Biomedical Innovation and

School of Biomedical Sciences, Queensland

University of Technology, Brisbane, Australia

Translational Research Institute, Brisbane, Australia

S. Maheswaran $(\bowtie)$

Massachusetts General Hospital Cancer Center,

Harvard Medical School, Charlestown, MA, USA

Department of Surgery, Massachusetts General

Hospital, Harvard Medical School,

Boston, MA, USA

e-mail: maheswaran@helix.mgh.harvard.edu contribution to genomic instability and genetic diversity, tumor progression and therapeutic responses using cell culture, mouse models and circulating tumor cells enriched from patients.

\section{Keywords}

Breast cancer - Circulating tumor cells (CTCs) - Epithelial-mesenchymal plasticity (EMP) $\cdot$ Metastasis

\subsection{Defining Epithelial- Mesenchymal Plasticity}

Cancer metastasis, the major cause of patient mortality, is a complex multi-step process in which tumor cells become invasive, intravasate into the blood, survive in the circulation, extravasate out of the blood stream, and proliferate at the distal sites. During the early steps of metastasis, tumor cells lose apico-basal polarity through disruption of cell-cell interactions and cytoskeletal remodeling to support invasion [1]. These changes are reminiscent of the normal physiological process, epithelial to mesenchymal transition (EMT), that is required for gastrulation, neural crest cell migration, heart morphogenesis, organogenesis, and wound healing [1-7]. Utilization of EMT by cancer 
cells to migrate, invade, and survive when nonadherent provides an attractive model to understand the critical steps involved in the initiation of metastasis. The process of canonical EMT in cancer cells is generally attributed to epigenetic changes that are thought to be largely reversible upon removal of EMT stimuli, resulting in the reversion of this phenotype through mesenchymal-epithelial transition (MET). It is generally accepted that MET plays an important role in successful completion of the metastatic cascade with epithelial-like tumor formation [1, 7-11], and recently emerged controversies [12, 13] have been addressed $[14,15]$.

We will refer to these lineage switches as epithelial-mesenchymal plasticity (EMP) from this point forward to reflect the extensive bidirectional plasticity of the process. EMP phenotypes have been observed in cell culture and in mouse tumor models of breast, lung, prostate, pancreatic, colorectal, and ovarian cancers [16-18]. Detection of EMP in patient-derived tumor tissue specimens, however, has been complicated by the presence of stromal cells which express high levels of mesenchymal markers. As such, despite the dramatic invasive and tumorigenic phenotypes observed in mouse xenografts expressing EMP-regulating master transcriptional factors, Snail, Twist, and Slug among others, the direct observation of EMP in the metastasis of human epithelial cancers has remained elusive. Recently, tumor cells at various stages of EMP were detected in the blood of breast cancer patients, suggesting that EMP is not bimodal but is a continuous process [19]. These circulating tumor cells (CTCs) are extremely rare and are the putative precursors of metastasis. Therefore, defining EMP as a single dramatic transition between two states may be an oversimplification and may limit the study of EMP in some circumstances [7]. In this chapter, we will review the process of EMP, the evidence for EMP in clinical samples, its contribution to breast cancer dissemination (with a focus on the metastatic intermediates, CTCs), and the therapeutic implications associated with this process.

\subsubsection{Epithelial-Mesenchymal Plasticity to Model the Early Steps of Metastasis}

During EMP, epithelial cells within the primary tumor switch lineage to take on a more mesenchymal phenotype $[1,20]$, which is associated with morphological changes and molecular reprogramming $[5,21]$. This consists of a series of sequential processes: the loss of apico-basal polarity due to cytoskeletal and junctional remodeling, increased cell migration as the result of decreased cell-cell adhesion and increased motility (sometimes at the cost of proliferation), and the acquisition of invasive properties such as passage through a basement membrane [1]. The basement membrane between the epithelia and nearby blood vessels is the first barrier encountered by invading cells [22]. Invasion requires breach of the basement membrane, then breakdown of the extracellular matrix in the stroma by proteases such as matrix metalloproteinases [23]. EMP regulates expression of many of the genes required for this breach of the basement membrane and matrix. Upon arrival at the secondary site, MET then proceeds in the reverse order, with increased polarity and cell-cell adhesion leading to decreased cell migration and an epithelial phenotype associated with increased proliferation. The steps of this process are highlighted in Fig. 2.1.

\subsubsection{Inducers and Effectors of EMP}

EMP in both development and cancer is induced and maintained by a variety of signals: (i) extracellular signals, (ii) master transcription factors, and (iii) post-transcriptional regulators. Extracellular signals regulating EMP consist of peptide growth factors (e.g. FGF, EGF, HGF, TGF $\beta$ ), cytokines, differentiation factors (Wnt, Notch, SHH, NFкB pathways, RAS/receptor tyrosine kinases), and hormones secreted by the cancer cells themselves as well as the supporting cells in the tumor microenvironment $[1,7,24-$ 30]. Additionally, hypoxia and extracellular com- 


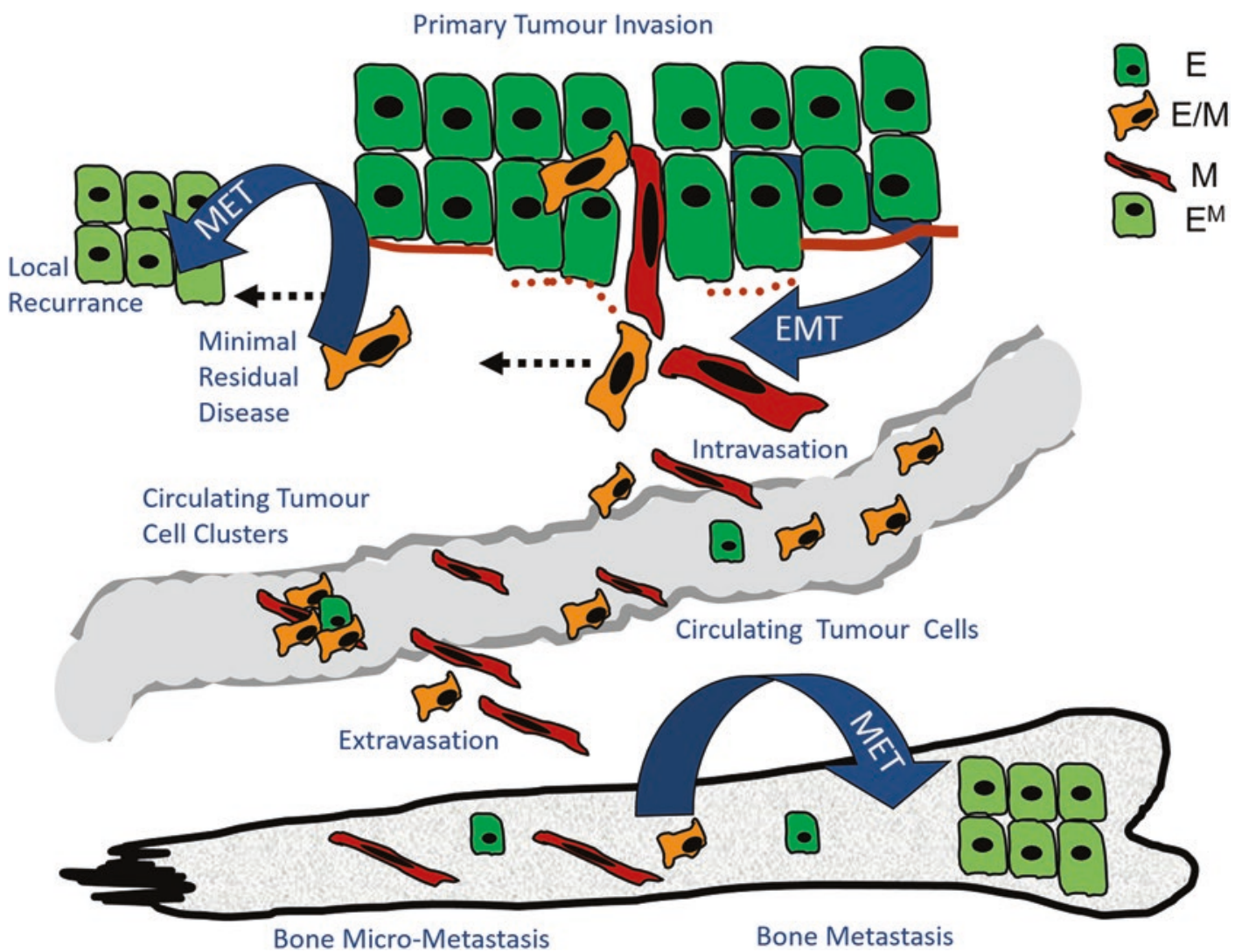

Fig. 2.1 Metastatic cascade highlighting CTC and EMP characteristics. A small proportion of carcinoma cells exhibit epithelial mesenchymal plasticity, resulting in hybrid $(\mathrm{E} / \mathrm{M})$ phenotype rather than a distinctly mesenchymal phenotypes (M). These mesenchymally shifted cells are associated with loss of the basement membrane and migration / invasion into the tumor microenvironment, where they can remain dormant. Epithelial change in these cells is likely to underpin local recurrence, allowing a new colony to form. A higher proportion of mesenchymally shifted (E/M) cells is found in the vasculature as circulating tumor cells

ponents such as collagen also can induce EMP [1, 25-29, 31-33]. These extracellular signals are transduced to transcription factors that regulate the expression changes required to elicit epithelial-mesenchymal state change. The master transcriptional regulators of EMP include Snail/ Slug, Twist, and members of the Zeb transcription factor family $[1,34]$. EMP is also regulated by post-transcriptional processes including ubiq-
(CTCs), indicating their increased capacity for intravasation and survival in the vasculature. A full spectrum of epithelial (E) to mesenchymal phenotypes is seen in the blood however, the hybrid phenotype dominates. CTC clusters containing cells at different stages of the EMP spectrum, and also normal immune cells and in some cases, tumor stromal cells, are also seen and have a higher prognostic value and a higher patho-biological potential. Dormant single cells / micrometastatic deposits can be seen in the bone marrow (depicted) or other metastatic sites. MET results in slightly altered gene expression profiles $\left(\mathrm{E}^{\mathrm{M}}\right)$

uitination, alternative splicing, and miRNAs that regulate protein translation, the most well characterized being the miR-200 family which modulates the expression of the (ZEB) proteins $[1,7$, 34-36].

Along with a multitude of additional modulators and chromatin modifiers, these regulators coordinate the expression of proteins that maintain the epithelial state, apico-basal polarity, and 
cell-cell adhesion, including Crumbs, PAR, Scribble, E-cadherin, $\alpha$-catenin, $\gamma$-catenin/plakoglobin, and claudin. They also regulate proteins defining the mesenchymal state, cellular motility, and invasiveness, including $\mathrm{N}$-cadherin, vimentin, and fibronectin $[1,7,19,34]$. Together, these many inputs create a broad and often redundant signaling network to induce and maintain these states of plasticity in tumor cells $[1,2,5,25-27$, 37-41].

\subsubsection{EMP in Cancer Stem Cells and Drug Resistance}

In addition to being involved in promoting metastasis, EMP has also been implicated in contributing to the maintenance of cancer stem cells (CSC). Like CSCs, cells undergoing EMP can survive under adverse conditions and exhibit resistance to chemotherapeutic interventions, although they do not necessarily self-renew [42]. Cells undergoing EMP coincidently acquire many CSC markers. In breast cancer, the presence of mesenchymal markers correlated with the presence of CSC markers including ALDH1, NANOG, OCT-4, and CD44 [43]. Double knockdown of the cancer stemness markers NANOG and OCT-4 reversed EMT in lung adenocarcinoma, while induction of these genes promoted EMT in breast cancer [43]. Similarly, knockdown of the OVOL2 transcription factor in nasopharyngeal carcinoma cells decreased both EMT and stemness [44]. Upregulation of CSC markers and the appearance of a CSC phenotype during EMP has been observed in cell lines, mouse models, and patient samples [43, 45-48]. However, EMP is not always associated with the appearance of CSClike properties. CSCs consist of both mesenchymal and epithelial phenotypes under different contexts, while EMT is often associated with a more mesenchymal state [49]. Further, CSCs represent a minor population of all tumor cells, whereas EMP occurs in a much larger fraction of tumor cells suggesting that additional criteria are involved in defining the functional characteristics of CSCs [50]. Further studies are required to better define the relationship between EMP and CSCs, specifically whether they represent a common phenomenon and if they are both induced and maintained through the same inducers and pathways.

Across several cancer types, the mesenchymal state is associated with increased drug resistance while the epithelial state is associated with increased sensitivity [34, 51-53]. In a mouse model of breast cancer, cells forced to revert to the epithelial state lost CSC markers and were increasingly sensitive to doxorubicin, paclitaxel, proteasome inhibitors, and MAPK/ EGFR inhibitors [54, 55]. Further, neoadjuvant chemotherapy in breast cancer has been shown to be ineffective against CTCs in the EMP state $[56,57]$. EMP signatures were also found to be associated with treatment response and resistance in non-small cell lung carcinoma, pancreatic, breast, and ovarian cancer [5, 12, 13, 30, 58-60]. The mechanistic aspects of EMP thought to confer drug resistance are similar to those in CSCs and include elevated expression of antiapoptotic proteins and drug efflux transporters and immunosuppression through the activities of EMP master transcription factors $[50,61]$.

\subsubsection{Significance of EMP in Non- epithelial Cancers}

While EMP is important for tumors of epithelial origin to migrate to the metastatic site, tumors of non-epithelial origin - leukemias, lymphomas, myelomas, sarcomas, and brain and spinal cord cancers - do not necessarily encounter these barriers. For some non-epithelial cancers, such as glioblastoma, markers of EMP are still induced by microglia and macrophages via $\mathrm{NFkB}$ and support invasiveness $[30,62,63]$. Further, of the four glioblastoma subtypes, the mesenchymal subtype is the most aggressive and radioresistant [64-66]. In sarcomas such as osteosarcoma and 
rhabdomyosarcoma, where the cell of origin is already highly mesenchymal, further upregulation of the EMP transcription factor ZEB1 has been observed compared to normal tissue, and SNAIL expression was associated with poorer overall survival [67-69]. Higher expression of epithelial E-cadherin is also associated with improved survival in bone and soft tissue sarcomas [70].

\subsubsection{Contribution of EMP to Genomic Instability and Genetic Diversity}

A series of studies published several years ago showed that mitosis during Drosophila and Xenopus embryogenesis is actively inhibited in cells undergoing gastrulation. Premature induction of proliferation before the completion of gastrulation in cells undergoing EMP results in extensive developmental abnormalities [71-74]. Recent studies show that this embryonic process is exploited by the tumor cells to drive genomic instability and diversity [75] - changes that can have profound consequences on tumor progression and drug responses. Although transitioning of epithelial cells to a mesenchymal state is reversible upon removal of the EMP inducers, the induced abnormalities in ploidy and genomic heterogeneity are heritable. The mechanistic clue to this incompatibility came from detailed proteomic analysis, which revealed that several nuclear envelope proteins are suppressed as epithelial cells transition to a mesenchymal state. Nuclear envelope proteins, in addition to providing the structural framework of the nucleus and selectively modulating the passage of molecules between the cytoplasm and the nucleoplasm, also play critical roles in orchestrating proper mitosis. Therefore, while the suppression of nuclear envelope proteins reduces the rigidity of the nucleus to facilitate EMP-associated migration and invasion, the requirement of these proteins for mitosis $[76,77]$ might also render their decrease during EMP incompatible with simultaneous prolifera- tion. Subsequent studies show that clonal epithelial populations spontaneously generate mesenchymal variants, which can revert to an epithelial phenotype [78] contributing to chromosome instability and the selection of robust variants capable of forming metastatic tumors. Disruption of tissue architecture associated with this cell fate switch has also been implicated in maintaining the fidelity of chromosome segregation [79].

\subsubsection{Mouse Models of EMP}

The inherent plasticity of EMP makes unequivocal determination of the lineage for a given cell difficult. Most studies evaluating the role of EMP in disease progression in vivo have relied on xenograft mouse models and cultured cells. Experimental induction of EMP in cancer cells led to an increase in metastasis, and knockdown of EMP or premature induction of MET reduced metastasis [47, 80-82]. Interestingly, expression of the EMT-inducing homeobox transcription factor, Prrx1, led to EMT phenotypes in cultured cancer cells [47]. However, loss of Prrx 1 in cultured cells was required for efficient metastasis upon tail vein injection or orthotopic tumor formation in mice [47]. Other studies utilized mouse models with intrinsic EMP reporters and gain-offunction or loss-of-function of EMP master transcription factors $[13,20]$. In skin-specific Twist1-inducible mice, Twist1 induction caused higher rates of squamous cell cancer development upon treatment with a carcinogen [83]. Reversal of this Twist1 induction upon tumor cell dissemination significantly increased metastasis. Together with the Prrx1 data, this result strongly supports a role for MET in metastatic outgrowth [83]. Single-cell lineage tracing with reporter genes irreversibly activated by lineage-specific promoters have been used to query the fate of the cells experiencing EMP. Reporter genes thus activated by epithelial/mesenchymal promoters have been used to track EMP in mouse models and monitor the change in cellular states during 
the course of metastasis and tumor progression [84]. Breast cancer models have found that a small fraction of primary and metastatic tumor cells undergo EMT [12]. Conversely, pancreatic cancer models showed about half of tumor cells had undergone EMT, rarely occurring in premalignant lesions [85]. However, given the complex signaling networks involved in promoting EMP, it is difficult to reach concrete conclusions based on studies that rely on a single marker in a given model, particularly in the context of the EMP hybrid phenotype, where the degree of induction may be less strong.

\subsubsection{Detecting EMP in Clinical Samples}

Although lineage tracing in humans is not possible and acquisition of serial samples is quite difficult, evaluation of epithelial and mesenchymal markers in patient-derived tissue provides a snapshot of EMP in the clinical setting. Immunohistochemistry (IHC) of human breast cancer samples with mesenchymal markers such as vimentin, $\mathrm{N}$-cadherin, cell cycle, and tumor specific markers such as HER2, showed evidence for EMT in triple negative and basal-like tumors but not in invasive lobular carcinomas [86, 87]. RNA in situ hybridization (RNA-ISH) using multiple probes to detect both epithelial and mesenchymal transcripts in the same samples delineated the ratios of epithelial and mesenchymal tumor cell populations at the single cell level in the primary tumors and draining lymph nodes of human breast cancer specimens [19]. While most tumor cells exhibited an epithelial phenotype, triple negative breast cancer was enriched for cells with mesenchymal markers, and all subtypes contained rare cells with combined epithelial and mesenchymal staining [19]. RNA-ISH analysis was also performed on CTCs from breast cancer patients, where it performed significantly better at detecting mesenchymal cells compared to standard cytokeratin approaches (discussed in more detail below) [19]. CTCs provide a noninvasive tool to monitor EMP in real time as patients progress through therapeutic interventions.

\subsection{EMP in Circulating Tumor Cells}

During metastasis, CTCs - the putative metastatic precursors - travel through the blood. Although the majority of CTCs are destroyed in the blood through apoptosis, the remaining viable cells reach and reside within distal sites in a dormant state until they adjust to the new microenvironment and eventually proliferate. The relative accessibility of CTCs in the peripheral blood provides real time sampling of tumor cells to interrogate the contribution of EMP to metastasis and drug responsiveness [30].

Studies of CTCs provide some of the best evidence for the involvement of EMP in promoting metastasis. Mesenchymal markers have been observed in CTCs from patients with glioblastoma, breast, liver, nasopharyngeal, colon, gastric, bladder, pancreatic, and non-small cell lung cancers [7, 19, 30, 54, 56, 80, 88-97]. A summary of EMP studies in breast cancer CTCs is shown in Table 2.1. These studies showed that CTCs are a heterogeneous population and, as predicted, exhibit more mesenchymal characteristics compared with the cells in the primary or metastatic tumors. A large fraction of individual CTCs was also found to express both epithelial and mesenchymal markers, suggesting that plasticity is a common component of the metastatic phenotype $[7,19,30,56,80,91-96]$. Lineage tracing experiments in animal models will be required to explore the stage of tissue residence or circulation at which CTCs undergo both EMT and MET [7].

\subsubsection{Hybrid-EMP and CTC Clusters}

Recent studies regarding EMP in CTCs address a longstanding dispute in the field: whether EMP should be defined as a binary process with epithelial and mesenchymal endpoints as observed in most non-disease cases (with notable exceptions 


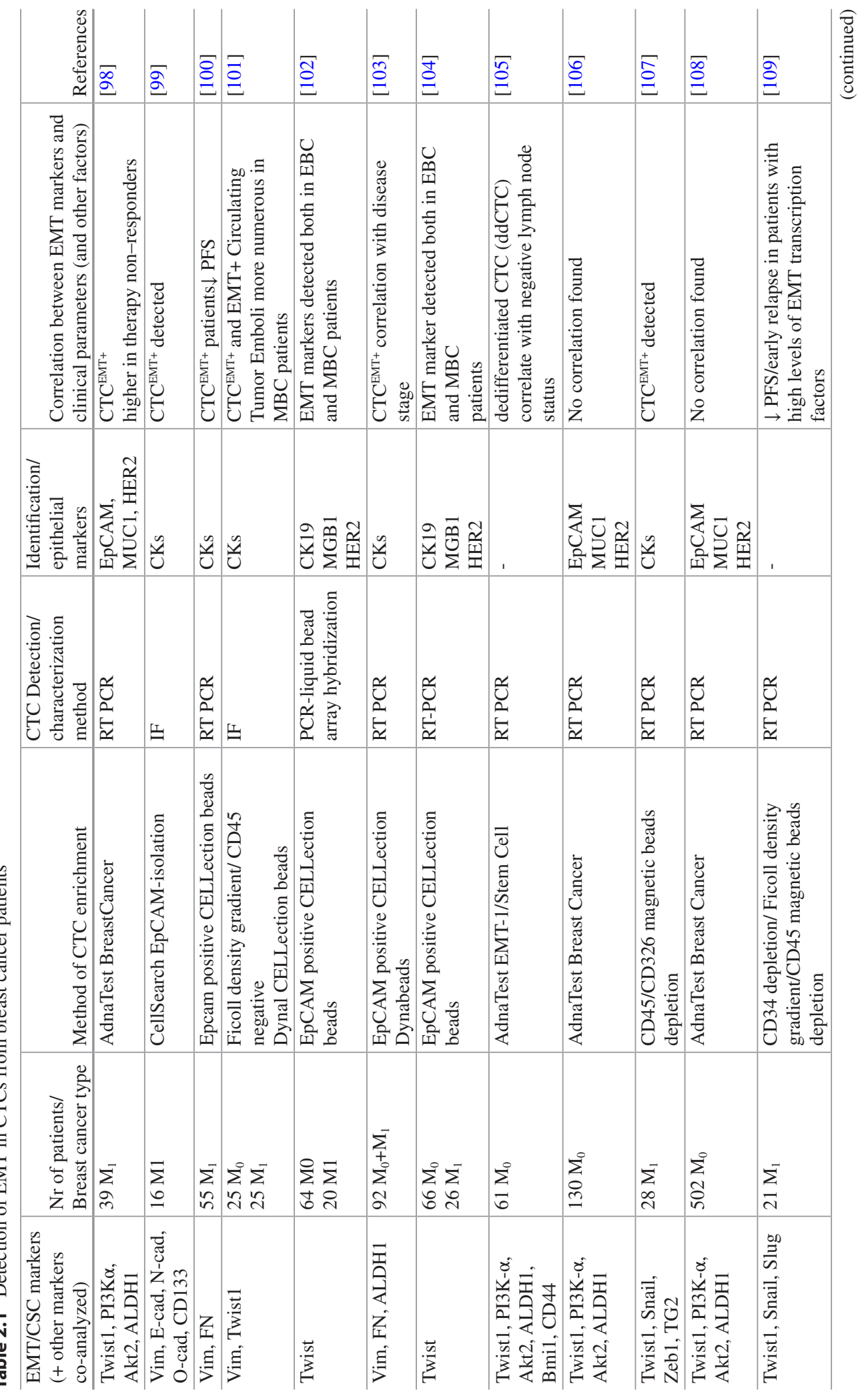




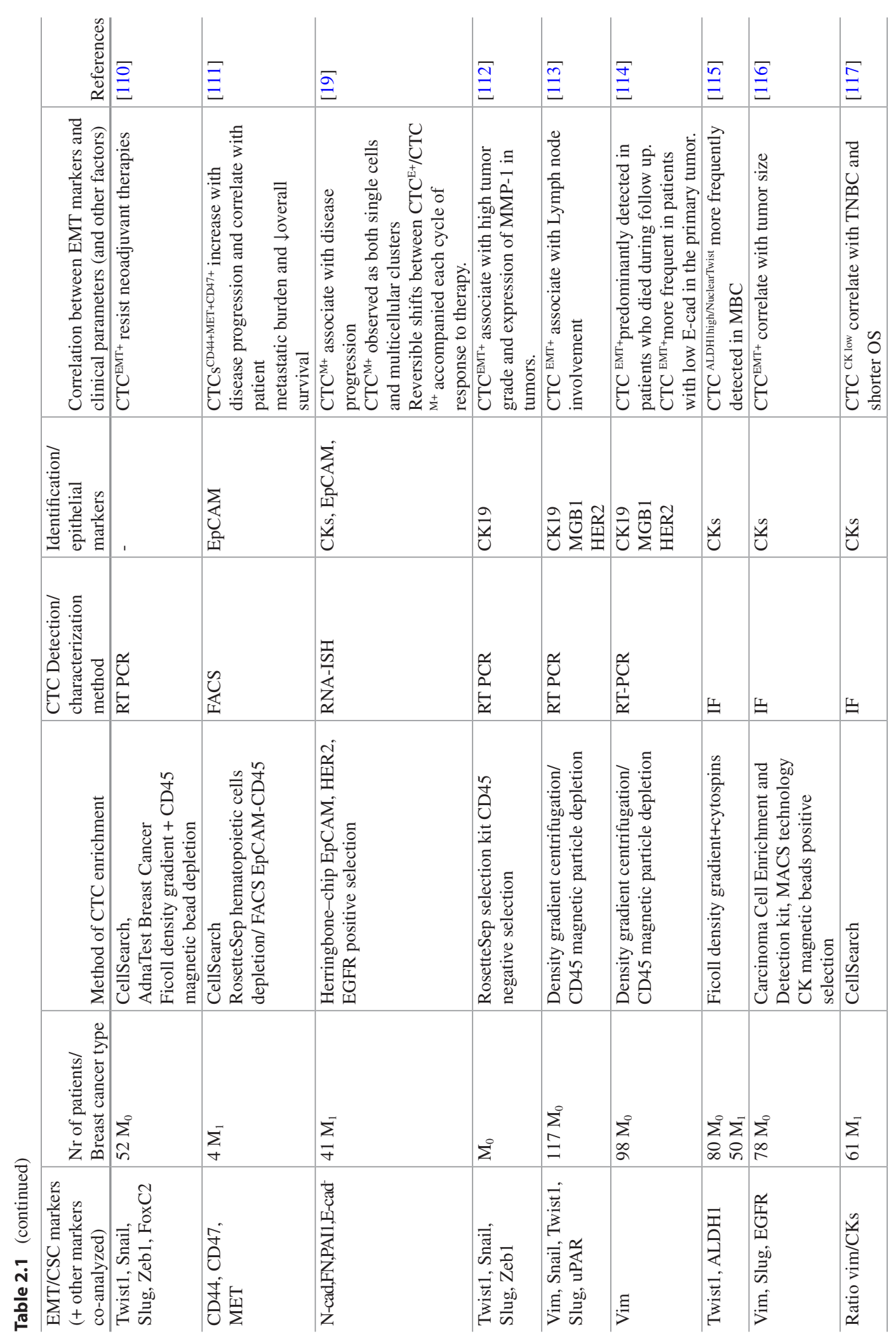




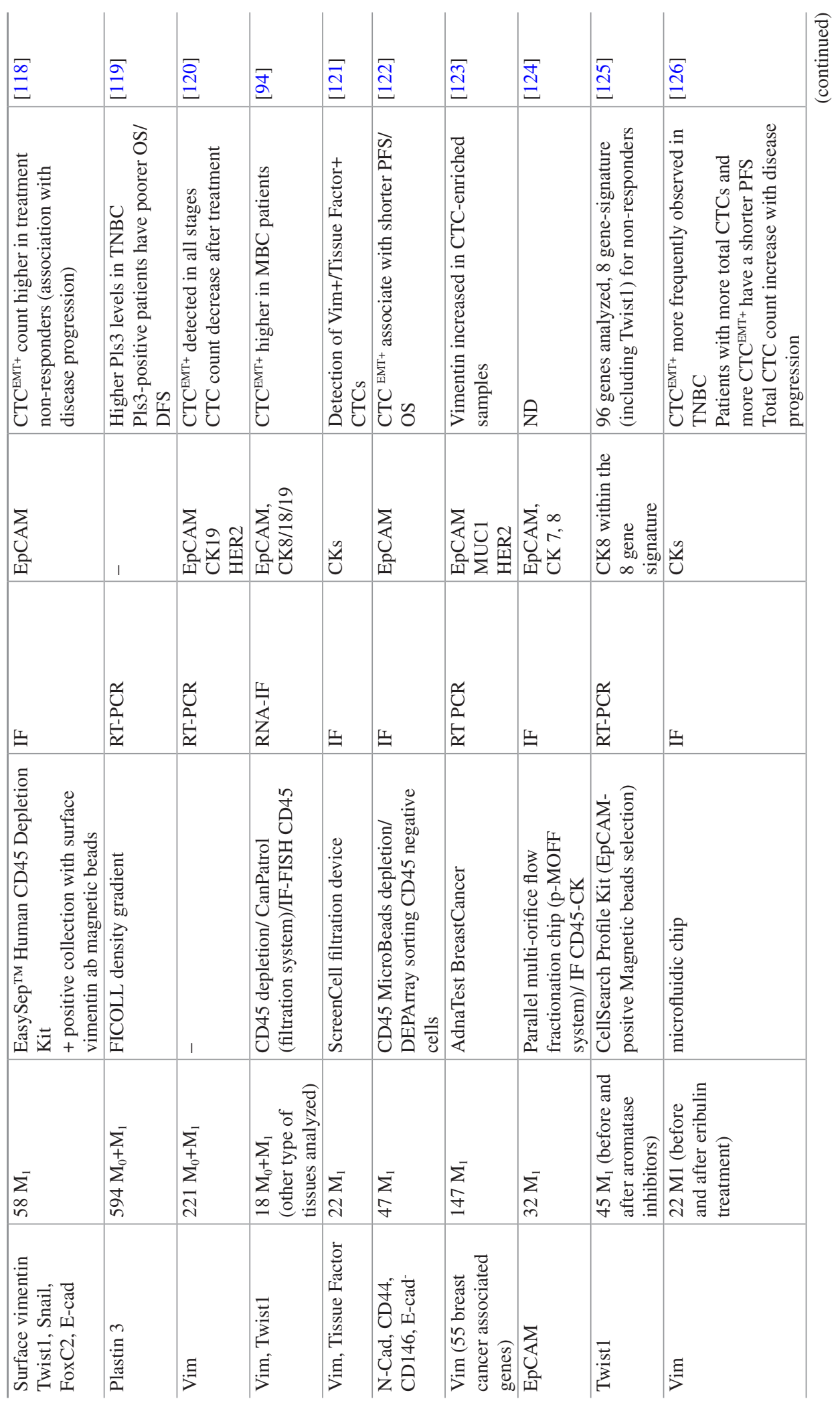




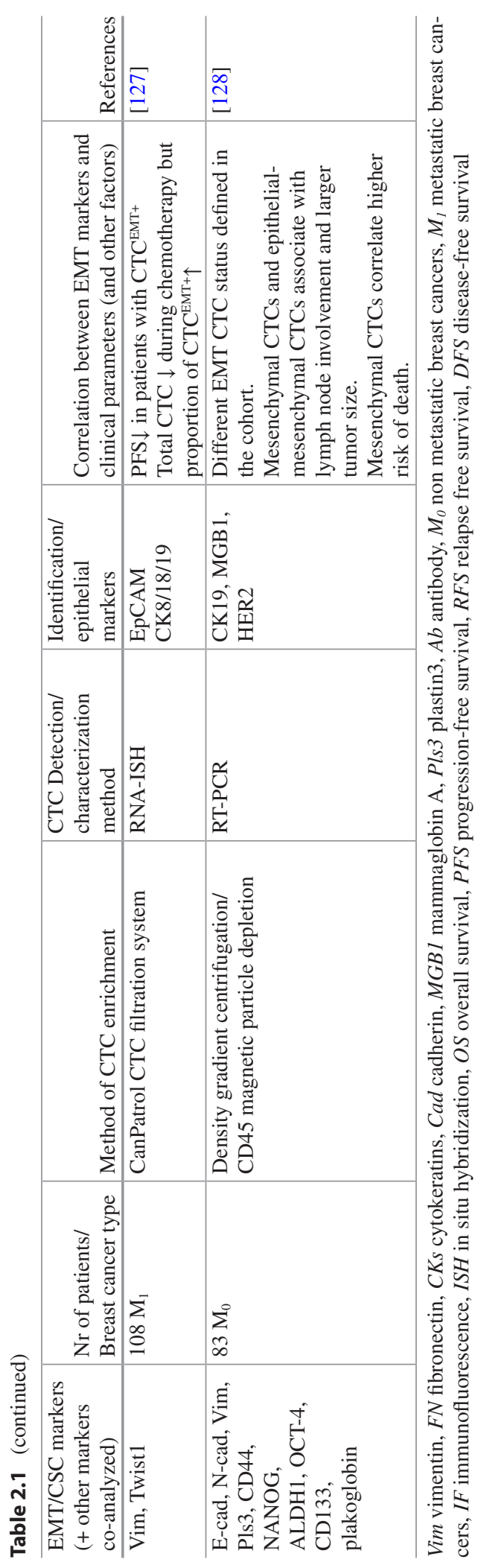


of cohort migration as outlined below), or whether EMP is a spectrum phenotype with potentially stable higher-plasticity manifestations along the continuum from epithelial to mesenchymal phenotype [1,53]. Highly-plastic cells with both epithelial and mesenchymal phenotypes (hereafter referred to as hybrid-EMP) are observed in many CTCs as well as in vivo; in fact, hybrid-EMP CTCs are more commonly observed than fully mesenchymal cells in many studies [8, 129]. Two recent studies of mouse pancreatic ductal adenocarcinoma (PDAC) and skin squamous cell cancer showed that these hybrid-EMP cells are more plastic than either epithelial or mesenchymal cells, with a higher ability to interconvert among the types in culture [8, 129]. Epigenetic, transcriptional, and posttranscriptional mechanisms were identified as regulating this interconversion, suggesting further study is needed to devise a unified mechanism for hybrid-EMP plasticity or to identify disease-specific mechanisms [8, 129]. Based on this data, we and others define EMP as a spectrum of phenotypes with highly plastic interconversion among the different states, with increased appreciation that the location of any particular cell along this continuum has important implications for both cancer and development $[1,7,8$, 129-137]. However, it is important to note that while the existence and importance of hybridEMP is accepted, it is still unclear whether it represents an intermediate phase during EMP or a final state, and even whether the same signaling pathways at work during EMP are also responsible for hybrid-EMP [7, 8].

Practically, the label hybrid-EMP is assigned to varied states, which include cells that downregulate epithelial markers but do not upregulate the full complement of mesenchymal markers, as well as cells expressing both epithelial and mesenchymal markers [8, 129]. For example, cells with upregulation of mesenchymal processes such as loss of polarity and increased motility and invasion but without loss of cell-cell adhesion or cell individualization. Indeed, although individual cell migration is a hallmark of EMT, recent studies have highlighted the presence of multicellular CTC clusters (up to 100 cells) in the circulation of patients with advanced cancers such as inflammatory breast cancer, and cohort migration is accepted as a frequent mode of invasion [1, 51, 138-147]. Clusters are more effective at colonizing secondary sites than single CTCs and correlate with a worse prognosis $[7,19,80$, 139]. Importantly, there is an association between CTC expression of mesenchymal markers and cluster formation. Many clusters are coated in platelets, which are a source of TGF $\beta$ and may help induce or maintain mesenchymal characteristics $[30,148]$. These clusters necessarily maintain cell-cell contacts and some epithelial-like expression (notably the desmosomal protein plakoglobin), suggesting that they exhibit the hybrid-EMP phenotype described above [8, 51, $80,149,150]$. Indeed, tumor spheres of hybridEMP mouse prostate cancer cells exhibited collective cell migration and cluster delamination while fully mesenchymal spheres only showed single-cell invasion [8]. It is not clear whether hybrid-EMP clusters are composed of a homogenous population of hybrid-EMP CTCs versus a mixed population of epithelial CTCs and mesenchymal CTCs [80]. However it is important to note that lineage tracing and tumor transplantation experiments show that CTC clusters do not form in the bloodstream through aggregation of single CTCs, but originate from polyclonal primary tumors, suggesting that the hybrid-EMP phenotype is established before invasion into the circulation [139, 151]. Although these clusters may seem impossibly large for invasion or extravasation through the blood vessel into the secondary tissue, studies have shown that CTC clusters can traverse the capillaries of Zebrafish by rapid reorganization into single-file chains [140]. Finally, although cohort migration is highlighted in the study of cancer CTCs, it should be noted that similar modes of invasion occur during development, wound healing, and mammary reorganization in some species, underscoring the fact that this hybrid-EMP phenotype is not restricted to the cancer environment [1]. 


\subsubsection{Role of EMP in CTCs During Progression and Therapeutic Response}

The implications of hybrid-EMP phenotypes on tumor histology and prognosis are significant. Hybrid-EMP cells are detected in both primary and metastatic tumors and are particularly prevalent in individual and clustered CTC populations as noted above [19]. Single-cell evaluation of both EMP markers and tumor-specific markers (such as HER2) in breast cancer confirm that these hybrid-EMP cells are tumor-derived [19]. Mesenchymal mouse PDAC tumors were poorly differentiated while hybrid-EMP tumors were moderately to well-differentiated [8]. Similar results are observed in human poorly differentiated quasi-mesenchymal, squamous, or basallike PDAC tumors versus well-differentiated classical/exocrine-like, classical, or pancreatic progenitor/ADEX tumors [8, 152-154]. The proportion of breast cancer CTCs with fully epithelial, predominantly mesenchymal, or hybrid-EMP seems to be dependent on tumor type and stage, consistent with data for primary and metastatic tumor cells. Pre-invasive ductal carcinoma in situ (DCIS) lesions exhibit exclusively epithelial phenotypes, while invasive breast cancers contain rare hybrid-EMP cells, suggesting incomplete MET [19]. Further, CTCs from patients with lobular type $(\mathrm{ER}+/ \mathrm{PR}+)$ cancers were predominantly epithelial while CTCs from patients with HER2+ or triple negative breast cancers were predominantly mesenchymal [19].

Studies show that EMP phenotypes in CTCs indicate poor prognosis and resistance to therapy. Hybrid-EMP mouse skin cancer cells produced more metastasis after tail vein injection than fully mesenchymal cells [129]. In humans, EMP CTCs confer poor prognosis in breast, prostate, liver, colorectal, head and neck, pancreatic, endometrial, and lung cancers [155]. HybridEMP cells are more anoikis-resistant and drugresistant $[53,156]$, giving them a better chance of metastatic colonization. Although the signaling pathways mediating anoikis resistance are not fully understood, EMP markers such as TGF $\beta$, Twist, Snail, and miR200 have also been shown to have effects on survival in circulation [157, 158]. This is particularly significant to breast cancer treatment, as apoptosis is the main inducer of regression in systemic therapy and resistance of disseminated tumor cells to apoptosis is correlated with worse prognosis [159]. EMP CTCs were also associated with chemotherapy or radiotherapy resistance in ovarian, breast, and colorectal cancer [109, 160, 161]. Interestingly, when one breast cancer patient was followed longitudinally, mesenchymal-CTCs decreased with therapy response and then increased upon development of resistance, a phenomenon that was observed over two successive rounds of treatment. This increase in mesenchymal-CTCs was accompanied by the appearance of CTC-clusters [19].

\subsubsection{The Influence of EMP on CTC Isolation Technologies}

The plasticity of mixed epithelial and mesenchymal CTC phenotypes in the blood has been highly consequential in defining the capture efficiency of antibody-based CTC isolation approaches that rely on the expression of the epithelial marker EpCAM on the surface of tumor cells. The only FDA approved technique for in vitro diagnostic use, CellSearch ${ }^{\circledR}$, (Veridex, Menarini Silicon Biosystems) uses immunomagnetic beads coated with antibodies against EpCAM. Other CTC isolation modalities rely on physical characteristics such as size, density, deformability, and charge. However, because CTCs are highly heterogeneous and many CTCs exhibit a hybrid-EMP or fully mesenchymal phenotype, enrichment by a single epithelial surface marker or physical characteristic may not be sufficient to capture the full array of CTCs in the blood [7]. To overcome this limitation, techniques using multiple antibodies that mark epithelial and mesenchymal states (e.g. a combination of EpCAM, cytokeratin, and vimentin) and tumor-specific cell surface markers including HER2 and EGFR have been more effective in sampling the different populations of CTCs circulating in the blood [19]. However, these "double positive" isolation technologies 
still fail to enrich for hybrid-EMP CTCs that express neither epithelial nor mesenchymal commonly examined markers [8]. Negative depletion of leukocytes with antibodies directed against white blood cells provides an efficient method to overcome the limitations posed by positive selection. These technologies rely on a permissive size-based separation to eliminate red blood cells followed by immunomagnetic depletion of white blood cells with CD45 antibodies [162-165]. They are considered negative selection because they enrich for CTCs based on known properties of the other cellular components of the blood, rather than making assumptions about CTC phenotypes that could bias the population of CTCs after isolation. The capability of each technique to isolate epithelial, mesenchymal, and hybridEMP CTCs is shown in Table 2.2. They each have their strengths and weaknesses, which are important to appreciate, however to date there in no universally accepted preferred method that allows comprehensive capture of all CTCs.

Table 2.2 Methods of CTC isolation and EMP recovery

\begin{tabular}{|c|c|c|c|}
\hline Method & Name & $\begin{array}{l}\text { Detection of Epithelial (E), } \\
\text { Mesenchymal (M), or Hybrid } \\
\text { (H) CTCs }\end{array}$ & References \\
\hline \multicolumn{4}{|l|}{ Physical separation } \\
\hline Size based filtration/microfluidics & $\begin{array}{l}\text { Microcavity array } \\
\text { (MCA); FAST disc; } \\
\text { CellSieve }\end{array}$ & $\mathrm{E}=\mathrm{M}=\mathrm{H}$ & [166-168] \\
\hline Density based centrifugation & Ficoll; OncoQuick & $\mathrm{E}=\mathrm{M}=\mathrm{H}$ & [169] \\
\hline Size and deformability & ISET®; Celsee & $\mathrm{M}>\mathrm{H}>\mathrm{E}$ & {$[170,171]$} \\
\hline Cell surface charge & PEG & $\mathrm{E}=\mathrm{M}=\mathrm{H}$ & [172] \\
\hline $\begin{array}{l}\text { Density based centrifugation followed by } \\
\text { invasion }\end{array}$ & CAM & $\mathrm{M}>\mathrm{E}$ & [173] \\
\hline \multicolumn{4}{|l|}{ Negative selection } \\
\hline $\begin{array}{l}\text { Microfluidic size based then negative } \\
\text { selection for CD } 45\end{array}$ & $\begin{array}{l}\text { CTC-iChip; } \\
\text { Cytelligen }{ }^{\circledR} \text { and iFISH }\end{array}$ & $\mathrm{E}=\mathrm{M}=\mathrm{H}$ & {$[162,163]$} \\
\hline $\begin{array}{l}\text { Density separation of tetrameric antibody } \\
\text { complexes for CD } 45, \text { CD } 66 \text { b and } \\
\text { glycophorin }\end{array}$ & RARE & $\mathrm{E}=\mathrm{M}=\mathrm{H}$ & [164] \\
\hline $\begin{array}{l}\text { Density gradient separation then } \\
\text { anti-CD } 45 \text { based negative } \\
\text { immunomagnetic enrichment }\end{array}$ & unnamed & $\mathrm{E}=\mathrm{M}=\mathrm{H}$ & [165] \\
\hline \multicolumn{4}{|l|}{ Positive selection } \\
\hline Cell surface vimentin & CSV 84-1 & M & [118] \\
\hline Cell surface EpCAM and FR $\alpha$ & unnamed & $\mathrm{E}=\mathrm{M}>\mathrm{H}$ & {$[174]$} \\
\hline $\begin{array}{l}\text { High throughput microscopy for } \\
\text { immunofluorescence or FISH }\end{array}$ & $\begin{array}{l}\text { Epic CTC Platform } ® ; \\
\text { FAST }\end{array}$ & $\mathrm{E}=\mathrm{M}>\mathrm{H}$ & [175-177] \\
\hline $\begin{array}{l}\text { EpCAM based immunomagnetic } \\
\text { separation }\end{array}$ & CellSearch ${ }^{\circledR}$ & $\mathrm{E}$ & {$[170]$} \\
\hline $\begin{array}{l}\text { Microfluidic size based then EpCAM } \\
\text { based immunomagnetic separation }\end{array}$ & $\begin{array}{l}\text { CTC-chip; } \\
\text { Herringbone; eDAR; } \\
\text { OncoBean }\end{array}$ & $\mathrm{E}$ & {$[178-181]$} \\
\hline $\begin{array}{l}\text { Sized based filtration then EpCAM, CK, } \\
\text { vimentin, and twist RNA-ISH }\end{array}$ & CanPatrol & $\mathrm{E}=\mathrm{M}>\mathrm{H}$ & [94] \\
\hline $\begin{array}{l}\text { Flow Cytometry for surface epithelial } \\
\text { markers }\end{array}$ & IE/FC & $\mathrm{E}$ & {$[182]$} \\
\hline $\begin{array}{l}\text { Filtration using selective size } \\
\text { amplification }\end{array}$ & SSA-MOA & $\mathrm{E}$ & [183] \\
\hline \multicolumn{4}{|l|}{ Clusters } \\
\hline Size based filtration & FMSA; Cluster-Chip & $\mathrm{M}=\mathrm{H}>\mathrm{E}$ & $\begin{array}{l}{[143,144,} \\
184]\end{array}$ \\
\hline
\end{tabular}




\subsection{Clinical Correlates and Future Study}

\subsubsection{EMP as a Biomarker for Progression, Aggressiveness, and Drug Selection}

The functional connections between EMP and cancer progression are well-established and are supported by prognostic correlations observed in patient-derived samples. In ovarian cancer, higher EMP scores are correlated with worse prognosis, both for overall and disease-free survival [156]. In metastatic breast, pancreatic, and hepatocellular carcinomas, increases in EMP CTCs are associated with progression, poor therapeutic response, metastasis, and worse prognosis while patients responding to therapy show a decrease in EMP CTCs [7, 19, 43, 80, 93, 95, 127]. The hybrid-EMP phenotype predominates in many cancer types, including aggressive breast cancer and melanoma, and may therefore indicate a worse prognosis than tumors with a purely mesenchymal phenotype [80]. Further, cancer cells exhibiting hybrid-EMP were more plastic, and more efficient in tumor budding, invasion, stemness, CTC cluster formation, and drug resistance $[34,51]$. Because CTCs are hematogenously circulating and represent many stages of metastasis, evaluation of EMP in CTCs may have clinical relevance as a biomarker [93]. However, these studies are still preliminary and the prognostic value of EMP CTCs in monitoring therapeutic resistance or progression has not been fully determined and no recommendation for clinical monitoring has been issued $[127,185]$.

\subsubsection{Prevention or Reversal of EMP as a Therapeutic Target}

In addition to serving as a biomarker, EMP may be an attractive therapeutic target to slow or halt metastasis. Current clinical trials aiming to prevent or reverse EMT are testing TGF $\beta$ inhibition (LY2157299 in glioblastoma and hepatocellular carcinoma), clusterin (a TGF $\beta$ mediator) inhibi- tion (AB-16B5 in advanced solid tumors), platelet inhibition (aspirin in metastatic breast and colorectal cancer), AXL inhibition (TP-0903 in refractory solid tumors), and Src kinase inhibition, with mixed results [186-192]. Reversing transition to a mesenchymal state through redifferentiation could reduce invasiveness and resensitize cells to current therapies. However, there are concerns associated with therapies targeting EMP. First, MET is likely required for outgrowth at the secondary site and therefore such a treatment may actually support metastasis, possibly through reactivating dormant tumor cells [47, 83, 193-196]. Indeed, knockdown of the EMP transcription factors PRRX1 and Twist1 in breast cancer cells increased lung metastasis in mice [47]. Reciprocally, induction of Twist1 in a skin cancer model inhibited metastatic outgrowth [83]. Second, even if we could be confident that EMP inhibition would not be detrimental to the patient, the benchmarks for such a reversal are unclear. As described, EMP is not a single phenotype, but a broad array of intermediate states in different cells. It is therefore difficult to determine how far along the EMP continuum to reverse the cells, and how to achieve consistent effects in such a heterogeneous population. The best course of action will likely be different for different contexts and cancer types, further complicating the issue [7].

\subsection{Controversies}

Two papers published in 2015 using lineage tracing mouse models raised doubts about whether EMP is strictly necessary for metastasis in vivo (although they maintain support for a role in chemoresistance) [12, 13, 30, 197]. However, numerous papers in response to these findings have drawn on decades of research in support of a role for EMP in metastasis, pointing out that the complexity of this dynamic process - with interactions between multiple transcription factors, important intermediate and hard to detect phenotypes, and necessary plasticity between epithelial and mesenchymal states to complete the metastatic cycle - makes it very difficult to interpret 
the results of a single lineage tracing model [7, $14,15,80,195]$. Future models of greater nuance relying on multiple EMP markers and single cell analysis will help to fully understand the role of EMP in metastasis.

\subsection{Remaining Questions}

Despite over 30 years of study, new and old questions remain to be addressed to clarify the role that EMP, and therefore CTCs and CTC clusters, play in metastasis. As we continue to probe further into the impact of EMP on tumorigenesis and metastasis, our increased awareness of the hybrid-EMP phenotypes exhibited by many tumor cells, but especially CTCs, will provide more insight into this process. Further studies are needed to define how many distinct subtypes there are within the continuum, how stable/plastic these subtypes are relative to each other, and whether their functional characteristics remain the same across different cancer types. This will require a collaborative decision regarding the markers of epithelial and mesenchymal phenotypes, the setting of thresholds for expression, and establishing of assays that mimic interconversion between states in patients. It will also need to be determined whether these hybrid-EMP subtypes are best modeled as a continuum or as a trans-differentiation. This will be informed by studies examining how cells transition between the subtypes, including examinations of both transcriptional and post-transcriptional regulations.

Beyond defining hybrid-EMP, it is becoming clear that hybrid-EMP in CTCs and tumor cells alike is correlated with a worse prognosis and higher metastatic potential that fully epithelial or mesenchymal cells $[53,129]$. It remains to be determined whether it is the hybrid-EMP cells themselves, or just the existence of a more heterogeneous population of tumor cells, that is the cause of this observation. On the one hand, metastasis requires both mesenchymal and epithelial processes, and cells locked into a mesenchymal state may fail to initiate a tumor in the secondary site. It is possible that hybrid-EMP
CTCs encompass the population of CSCs that are the crucial determinants of successful tumor reinitiation. On the other hand, different cancer types and individual cancers exhibit different levels of hybrid-EMP, and yet many cancers are metastatic. With the recent identification of CTC clusters and the appreciation of their higher metastatic potential, it is possible that heterogeneous clusters of CTCs, containing cells with epithelial, hybrid-EMP, and mesenchymal phenotypes can form and cooperatively make the metastatic journey, with the mesenchymal cells "shepherding" the epithelial cells to their destination. Our ability to address these and other mechanistic questions will be aided by technological developments. Already, CTC isolation technologies have given us an opportunity to study some of these questions in the most appropriate setting - invaded cells that are the putative precursors of metastasis. Because these rare cells must be enriched, it will be crucial to select the appropriate isolation technology so that our evaluation of the breadth of EMP phenotypes in CTCs is not biased. To confidently accomplish this, we will need to standardize epithelial, mesenchymal, and CTC markers. Upon isolation of a physiologically relevant CTC population, advances in genomics and proteomics will allow for comprehensive mapping of transcriptional, epigenetic, and posttranscriptional differences in EMP phenotypes in individual CTCs and throughout disease progression. Finally, although CTCs are the metastatically competent population, upon isolation they still provide only a snapshot in the EMP progression of that cell. As with all EMP studies, animal models and lineage tracing technologies will be crucial to visualize and ultimately understand the implications of EMP on metastasis in vivo.

\section{References}

1. Savagner P. Epithelial-mesenchymal transitions: from cell plasticity to concept elasticity. Curr Top Dev Biol. 2015;112:273-300. https://doi. org/10.1016/bs.ctdb.2014.11.021.

2. Lim J, Thiery JP. Epithelial-mesenchymal transitions: insights from development. Development. 2012;139(19):3471-86. https://doi.org/10.1242/ dev.071209. 
3. Nakaya Y, Sheng G. Epithelial to mesenchymal transition during gastrulation: an embryological view. Develop Growth Differ. 2008;50(9):755-66. https:// doi.org/10.1111/j.1440-169X.2008.01070.x.

4. Solnica-Krezel L, Sepich DS. Gastrulation: making and shaping germ layers. Annu Rev Cell Dev Biol. 2012;28:687-717. https://doi.org/10.1146/ annurev-cellbio-092910-154043.

5. Yu M, Smolen GA, Zhang J, Wittner B, Schott BJ, Brachtel E, et al. A developmentally regulated inducer of EMT, LBX1, contributes to breast cancer progression. Genes Dev. 2009;23(15):1737-42. https://doi.org/10.1101/gad.1809309.

6. Shaw TJ, Martin P. Wound repair: a showcase for cell plasticity and migration. Curr Opin Cell Biol. 2016;42:29-37. https://doi.org/10.1016/j. ceb.2016.04.001.

7. Nieto MA, Huang RY, Jackson RA, Thiery JP. Emt: 2016. Cell. 2016;166(1):21-45. https://doi. org/10.1016/j.cell.2016.06.028.

8. Aiello NM, Maddipati R, Norgard RJ, Balli D, Li J, Yuan S, et al. EMT subtype influences epithelial plasticity and mode of cell migration. Dev Cell. 2018;45:681-95.e4. https://doi.org/10.1016/j. devcel.2018.05.027.

9. Bedi U, Mishra VK, Wasilewski D, Scheel C, Johnsen SA. Epigenetic plasticity: a central regulator of epithelial-to-mesenchymal transition in cancer. Oncotarget. 2014;5(8):2016-29. https://doi. org/10.18632/oncotarget.1875.

10. McDonald OG, Wu H, Timp W, Doi A, Feinberg AP. Genome-scale epigenetic reprogramming during epithelial-to-mesenchymal transition. Nat Struct Mol Biol. 2011;18(8):867-74. https://doi. org/10.1038/nsmb.2084.

11. Micalizzi DS, Maheswaran S, Haber DA. A conduit to metastasis: circulating tumor cell biology. Genes Dev. 2017;31(18):1827-40. https://doi.org/10.1101/ $\operatorname{gad} .305805 .117$.

12. Fischer KR, Durrans A, Lee S, Sheng J, Li F, Wong $\mathrm{ST}$, et al. Epithelial-to-mesenchymal transition is not required for lung metastasis but contributes to chemoresistance. Nature. 2015;527(7579):472-6. https://doi.org/10.1038/nature15748.

13. Zheng X, Carstens JL, Kim J, Scheible M, Kaye $\mathrm{J}$, Sugimoto $\mathrm{H}$, et al. Epithelial-to-mesenchymal transition is dispensable for metastasis but induces chemoresistance in pancreatic cancer. Nature. 2015;527:525-30. https://doi.org/10.1038/ nature16064.

14. Ye X, Brabletz T, Kang Y, Longmore GD, Nieto MA, Stanger BZ, et al. Upholding a role for EMT in breast cancer metastasis. Nature. 2017;547:E1-6. https://doi.org/10.1038/nature22816.

15. Aiello NM, Brabletz T, Kang Y, Nieto MA, Weinberg RA, Stanger BZ. Upholding a role for EMT in pancreatic cancer metastasis. Nature. 2017;547(7661):E7-8. https://doi.org/10.1038/ nature 22963 .
16. Boyer B, Tucker GC, Valles AM, Franke WW, Thiery JP. Rearrangements of desmosomal and cytoskeletal proteins during the transition from epithelial to fibroblastoid organization in cultured rat bladder carcinoma cells. J Cell Biol. 1989;109(4 Pt 1):1495-509.

17. Weidner KM, Behrens J, Vandekerckhove J, Birchmeier W. Scatter factor: molecular characteristics and effect on the invasiveness of epithelial cells. J Cell Biol. 1990;111(5 Pt 1):2097-108.

18. Jolly MK, Ward C, Eapen MS, Myers S, Hallgren $\mathrm{O}$, Levine H, et al. Epithelial-mesenchymal transition, a spectrum of states: role in lung development, homeostasis, and disease. Dev Dyn. 2018;247:34658. https://doi.org/10.1002/dvdy.24541.

19. Yu M, Bardia A, Wittner BS, Stott SL, Smas ME, Ting DT, et al. Circulating breast tumor cells exhibit dynamic changes in epithelial and mesenchymal composition. Science. 2013;339:580-4. https://doi. org/10.1126/science. 1228522 .

20. Ye X, Tam WL, Shibue T, Kaygusuz Y, Reinhardt F, $\mathrm{Ng}$ Eaton E, et al. Distinct EMT programs control normal mammary stem cells and tumour-initiating cells. Nature. 2015;525:256-60. https://doi. org/10.1038/nature14897.

21. Hay ED. The mesenchymal cell, its role in the embryo, and the remarkable signaling mechanisms that create it. Dev Dyn. 2005;233(3):706-20. https:// doi.org/10.1002/dvdy.20345.

22. Sherwood DR. Cell invasion through basement mem- branes : an anchor of understanding. Trends Cell Biol. 2006;16:250-6. https://doi.org/10.1016/j. tcb.2006.03.004.

23. De Wever O, Mareel M. Role of tissue stroma in cancer cell invasion. J Pathol. 2003;200:429-47. https:// doi.org/10.1002/path.1398.

24. Wyckoff J, Wang W, Lin EY, Wang Y, Pixley F, Stanley ER, et al. A paracrine loop between tumor cells and macrophages is required for tumor cell migration in mammary tumors. Cancer Res. 2004;64(19):7022-9. https://doi.org/10.1158/00085472.CAN-04-1449.

25. De Craene B, Berx G. Regulatory networks defining EMT during cancer initiation and progression. Nat Rev Cancer. 2013;13(2):97-110. https://doi. org/10.1038/nrc3447.

26. Nieto MA, Cano A. The epithelial-mesenchymal transition under control: global programs to regulate epithelial plasticity. Semin Cancer Biol. 2012;22(5-6):361-8. https://doi.org/10.1016/j. semcancer.2012.05.003.

27. Zheng H, Kang Y. Multilayer control of the EMT master regulators. Oncogene. 2014;33(14):1755-63. https://doi.org/10.1038/onc.2013.128.

28. Dong L, Ge XY, Wang YX, Yang LQ, Li SL, Yu GY, et al. Transforming growth factor-beta and epithelial-mesenchymal transition are associated with pulmonary metastasis in adenoid cystic carcinoma. Oral Oncol. 2013;49(11):1051-8. https://doi. org/10.1016/j.oraloncology.2013.07.012. 
29. Giannoni E, Parri M, Chiarugi P. EMT and oxidative stress: a bidirectional interplay affecting tumor malignancy. Antioxid Redox Signal. 2012;16(11):1248-63. https://doi.org/10.1089/ ars.2011.4280.

30. Micalizzi DS, Haber DA, Maheswaran S. Cancer metastasis through the prism of epithelial-tomesenchymal transition in circulating tumor cells. Mol Oncol. 2017;11(7):770-80. https://doi. org/10.1002/1878-0261.12081.

31. Choi HY, Yoo Y, Kim J-H, Dayem AA, Yee C, Yang G-M, et al. Hydrodynamic shear stress promotes epithelial-mesenchymal transition by downregulating ERK and GSK3 $\beta$ activities. Breast Cancer Res. 2019;21:1-20. https://doi.org/10.1186/ s13058-018-1071-2.

32. Aiello NM, Bajor DL, Norgard RJ, Sahmoud A, Bhagwat N, Pham MN, et al. Metastatic progression is associated with dynamic changes in the local microenvironment. Nat Commun. 2016;7:12819. https://doi.org/10.1038/ncomms12819.

33. Jung HY, Fattet L, Yang J. Molecular pathways: linking tumor microenvironment to epithelialmesenchymal transition in metastasis. Clin Cancer Res. 2015;21(5):962-8. https://doi. org/10.1158/1078-0432.CCR-13-3173.

34. Garg M. Epithelial plasticity and metastatic cascade. Expert Opin Ther Targets. 2018;22:5-7. https://doi. org/10.1080/14728222.2018.1407312.

35. Voutsadakis IA. The ubiquitin-proteasome system and signal transduction pathways regulating Epithelial Mesenchymal transition of cancer. J Biomed Sci. 2012;19:67. https://doi. org/10.1186/1423-0127-19-67.

36. Bracken CP, Scott HS, Goodall GJ. A networkbiology perspective of microRNA function and dysfunction in cancer. Nat Rev Genet. 2016;17(12):719-32. https://doi.org/10.1038/ $\operatorname{nrg} .2016 .134$.

37. Lamouille S, Xu J, Derynck R. Molecular mechanisms of epithelial-mesenchymal transition. Nat Rev Mol Cell Biol. 2014;15(3):178-96. https://doi. org/10.1038/nrm3758.

38. Savagner P. Leaving the neighborhood: molecular mechanisms involved during epithelial-mesenchymal transition. Bioessays. 2001;23(10):912-23. https:// doi.org/10.1002/bies.1132.

39. Yang J, Weinberg RA. Epithelial-mesenchymal transition: at the crossroads of development and tumor metastasis. Dev Cell. 2008;14(6):818-29. https:// doi.org/10.1016/j.devcel.2008.05.009.

40. Casas E, Kim J, Bendesky A, Ohno-Machado L, Wolfe CJ, Yang J. Snail2 is an essential mediator of Twist1-induced epithelial mesenchymal transition and metastasis. Cancer Res. 2011;71(1):245-54. https://doi.org/10.1158/0008-5472.CAN-10-2330.

41. Dhasarathy A, Phadke D, Mav D, Shah RR, Wade PA. The transcription factors Snail and Slug activate the transforming growth factor-beta signaling pathway in breast cancer. PLoS One. 2011;6(10):e26514. https://doi.org/10.1371/journal.pone.0026514.

42. Yamauchi T, Fernandez JRE, Imamura CK, Yamauchi H, Jinno H, Takahashi M, et al. Dynamic changes in CD44v-positive cells after preoperative anti-HER2 therapy and its correlation with pathologic complete response in HER2-positive breast cancer. Oncotarget. 2018;9:6872-82. https://doi. org/10.18632/oncotarget.23914.

43. Markiewicz A, Nagel A, Szade J, Majewska H, Skokowski J, Seroczynska B, et al. Aggressive phenotype of cells disseminated via hematogenous and lymphatic route in breast cancer patients. Transl Oncol. 2018;11:722-31. https://doi.org/10.1016/j. tranon.2018.03.006.

44. Qi XK, Han HQ, Zhang HJ, Xu M, Li L, Chen L, et al. OVOL2 links stemness and metastasis via finetuning epithelial-mesenchymal transition in nasopharyngeal carcinoma. Theranostics. 2018;8:2202-16. https://doi.org/10.7150/thno.24003.

45. Mani SA, Guo W, Liao M-JJ, Eaton EN, Ayyanan A, Zhou AY, et al. The epithelial-mesenchymal transition generates cells with properties of stem cells. Cell. 2008;133:704-15. https://doi.org/10.1016/j. cell.2008.03.027.

46. Al-Hajj M, Wicha MS, Benito-Hernandez A, Morrison SJ, Clarke MF. Prospective identification of tumorigenic breast cancer cells. Proc Natl Acad Sci U S A. 2003;100(7):3983-8. https://doi. org/10.1073/pnas.0530291100.

47. Ocaña OH, Córcoles R, Fabra Á, Moreno-Bueno $\mathrm{G}$, Acloque $\mathrm{H}$, Vega $\mathrm{S}$, et al. Metastatic colonization requires the repression of the epithelialmesenchymal transition inducer Prrx1. Cancer Cell. 2012;22:709-24. https://doi.org/10.1016/j. ccr.2012.10.012.

48. Kroger C, Afeyan A, Mraz J, Eaton EN, Reinhardt F, Khodor YL, et al. Acquisition of a hybrid E/M state is essential for tumorigenicity of basal breast cancer cells. Proc Natl Acad Sci U S A. 2019;116(15):735362. https://doi.org/10.1073/pnas.1812876116.

49. Grosse-Wilde A, D'Hérouël AF, McIntosh E, Ertaylan G, Skupin A, Kuestner RE, et al. Stemness of the hybrid epithelial/mesenchymal state in breast cancer and its association with poor survival. PLoS ONE. 2015;10:1-28. https://doi.org/10.1371/journal.pone. 0126522 .

50. Shibue T, Weinberg RA. EMT, CSCs, and drug resistance: the mechanistic link and clinical implications. Nat Rev Clin Oncol. 2017;14:611-29. https://doi. org/10.1038/nrclinonc.2017.44.

51. Basu S, Cheriyamundath S, Ben-Ze'ev A. Cellcell adhesion: linking Wnt/ $\beta$-catenin signaling with partial EMT and stemness traits in tumorigenesis. F1000Research. 2018;7:1488. https://doi. org/10.12688/f1000research.15782.1. 
52. Redfern AD, Spalding LJ, Thompson EW. The Kraken Wakes: induced EMT as a driver of tumour aggression and poor outcome. Clin Exp Metastasis. 2018;35(4):285-308. https://doi.org/10.1007/ s10585-018-9906-x.

53. Jolly MK, Mani SA, Levine H. Hybrid epithelial/ mesenchymal phenotype(s): the 'fittest' for metastasis? Biochim Biophys Acta. 2018;1870:151-7. https://doi.org/10.1016/j.bbcan.2018.07.001.

54. Markiewicz A, Zaczek AJ. The landscape of circulating tumor cell research in the context of epithelial-mesenchymal transition. Pathobiology. 2017;84:264-83. https://doi. org/10.1159/000477812.

55. Witta SE, Gemmill RM, Hirsch FR, Coldren CD, Hedman K, Ravdel L, et al. Restoring E-cadherin expression increases sensitivity to epidermal growth factor receptor inhibitors in lung cancer cell lines. Cancer Res. 2006;66(2):944-50. https://doi. org/10.1158/0008-5472.CAN-05-1988.

56. Choynzonov E, Savelieva O, Slonimskaya E, Perelmuter V, Tashireva L, Tarabanovskaya N, et al. Heterogeneity of circulating tumor cells in neoadjuvant chemotherapy of breast cancer. Molecules. 2018;23:727. https://doi.org/10.3390/ molecules23040727.

57. Li H, Smolen GA, Beers LF, Xia L, Gerald W, Wang $\mathrm{J}$ et al. Adenosine transporter ENT4 is a direct target of EWS / WT1 translocation product and is highly expressed in desmoplastic small round cell tumor PLoS ONE. 2008;3. https://doi.org/10.1371/journal. pone.0002353.

58. Byers DE, Alexander-Brett J, Patel AC, Agapov E, Dang-Vu G, Jin X, et al. Long-term IL-33-producing epithelial progenitor cells in chronic obstructive lung disease. J Clin Invest. 2013;123(9):3967-82. https:// doi.org/10.1172/JCI65570.

59. Bryant JL, Britson J, Balko JM, Willian M, Timmons $\mathrm{R}$, Frolov A, et al. A microRNA gene expression signature predicts response to erlotinib in epithelial cancer cell lines and targets EMT. Br J Cancer. 2012;106(1):148-56. https://doi.org/10.1038/ bjc. 2011.465 .

60. Marchini S, Fruscio R, Clivio L, Beltrame L, Porcu L, Nerini IF, et al. Resistance to platinum-based chemotherapy is associated with epithelial to mesenchymal transition in epithelial ovarian cancer. Eur J Cancer. 2013;49:520-30. https://doi.org/10.1016/j. ejca.2012.06.026.

61. Kurrey NK, Jalgaonkar SP, Joglekar AV, Ghanate AD, Chaskar PD, Doiphode RY, et al. Snail and slug mediate radioresistance and chemoresistance by antagonizing p53-mediated apoptosis and acquiring a stem-like phenotype in ovarian cancer cells. Stem Cells. 2009;27:2059-68. https://doi.org/10.1002/ stem. 154.

62. Sandberg CJ, Altschuler G, Jeong J, Stromme KK, Stangeland B, Murrell W, et al. Comparison of glioma stem cells to neural stem cells from the adult human brain identifies dysregulated Wnt- signaling and a fingerprint associated with clinical outcome. Exp Cell Res. 2013;319(14):2230-43. https://doi. org/10.1016/j.yexcr.2013.06.004.

63. Ortensi B, Setti M, Osti D, Pelicci G. Cancer stem cell contribution to glioblastoma invasiveness. Stem Cell Res Ther. 2013;4(1):18. https://doi.org/10.1186/ scrt166.

64. Murat A, Migliavacca E, Gorlia T, Lambiv WL, Shay T, Hamou MF, et al. Stem cell-related "selfrenewal" signature and high epidermal growth factor receptor expression associated with resistance to concomitant chemoradiotherapy in glioblastoma. J Clin Oncol. 2008;26(18):3015-24. https://doi. org/10.1200/JCO.2007.15.7164.

65. Colman H, Zhang L, Sulman EP, McDonald JM, Shooshtari NL, Rivera A, et al. A multigene predictor of outcome in glioblastoma. Neuro-Oncology. 2010;12(1):49-57. https://doi.org/10.1093/neuonc/ nop007.

66. Bhat KPL, Balasubramaniyan V, Vaillant B, Ezhilarasan R, Hummelink K, Hollingsworth F, et al. Mesenchymal differentiation mediated by NF-kappaB promotes radiation resistance in glioblastoma. Cancer Cell. 2013;24(3):331-46. https:// doi.org/10.1016/j.ccr.2013.08.001.

67. Somarelli JA, Shetler S, Jolly MK, Wang X, Bartholf Dewitt S, Hish AJ, et al. Mesenchymal-epithelial transition in sarcomas is controlled by the combinatorial expression of microRNA 200s and GRHL2. Mol Cell Biol. 2016;36(19):2503-13. https://doi. org/10.1128/MCB.00373-16.

68. Shen A, Zhang Y, Yang H, Xu R, Huang G. Overexpression of ZEB1 relates to metastasis and invasion in osteosarcoma. J Surg Oncol. 2012;105:830-4. https://doi.org/10.1002/jso.23012.

69. Alba-Castellón L, Batlle R, Francí C, FernándezAceñero MJ, Mazzolini R, Peña R, et al. Snail1 expression is required for sarcomagenesis. Neoplasia. 2014;16:413-21. https://doi. org/10.1016/j.neo.2014.05.002.

70. Wang N, Qi Y, Zou H, Zhang W-J, Li F, Pang L-J, et al. Down-regulated E-cadherin expression is associated with poor five-year overall survival in bone and soft tissue sarcoma: results of a metaanalysis. PLoS One. 2015;10:e0121448. https://doi. org/10.1371/journal.pone.0121448.

71. Grosshans J, Wieschaus E. A genetic link between morphogenesis and cell division during formation of the ventral furrow in Drosophila. Cell. 2000;101(5):523-31.

72. Mata J, Curado S, Ephrussi A, Rorth P. Tribbles coordinates mitosis and morphogenesis in Drosophila by regulating string/CDC25 proteolysis. Cell. 2000;101(5):511-22.

73. Murakami MS. Morphogenesis during Xenopus gastrulation requires Wee1-mediated inhibition of cell proliferation. Development. 2004;131:571-80. https://doi.org/10.1242/dev.00971.

74. Seher TC, Leptin M. Tribbles, a cell-cycle brake that coordinates proliferation and morphogenesis during 
Drosophila gastrulation. Curr Biol. 2000;10:623-9. https://doi.org/10.1016/S0960-9822(00)00502-9.

75. Comaills V, Kabeche L, Morris R, Buisson R, Yu M, Madden MW, et al. Genomic instability is induced by persistent proliferation of cells undergoing epithelial-to-mesenchymal transition. Cell Rep. 2016;17:2632-47. https://doi.org/10.1016/j. celrep.2016.11.022.

76. Gruenbaum Y, Foisner R. Lamins: nuclear intermediate filament proteins with fundamental functions in nuclear mechanics and genome regulation. Annu Rev Biochem. 2015;84:131-64. https://doi. org/10.1146/annurev-biochem-060614-034115.

77. Guttinger S, Laurell E, Kutay U. Orchestrating nuclear envelope disassembly and reassembly during mitosis. Nat Rev Mol Cell Biol. 2009;10(3):17891. https://doi.org/10.1038/nrm2641.

78. Gao C, Su Y, Koeman J, Haak E, Dykema K, Essenberg C, et al. Chromosome instability drives phenotypic switching to metastasis. Proc Natl Acad Sci U S A. 2016;113(51):14793-8. https://doi. org/10.1073/pnas.1618215113.

79. Knouse KA, Lopez KE, Bachofner M, Amon A. Chromosome segregation fidelity in epithelia requires tissue architecture. Cell. 2018;175(1):20011 e13. https://doi.org/10.1016/j.cell.2018.07.042.

80. Diepenbruck M, Christofori G. Epithelialmesenchymal transition (EMT) and metastasis: yes, no, maybe? Curr Opin Cell Biol. 2016;43:7-13. https://doi.org/10.1016/j.ceb.2016.06.002.

81. Shaul YD, Freinkman E, Comb WC, Cantor JR, Tam WL, Thiru P, et al. Dihydropyrimidine accumulation is required for the epithelial-mesenchymal transition. Cell. 2014;158:1094-109. https://doi.org/10.1016/j. cell.2014.07.032.

82. Yang J, Mani SA, Donaher JL, Ramaswamy S, Itzykson RA, Come C, et al. Twist, a master regulator of morphogenesis, plays an essential role in tumor metastasis Ben Gurion University of the Negev. Cell. 2004;117:927-39. https://doi.org/10.1016/j. cell.2004.06.006.

83. Tsai JH, Donaher JL, Murphy DA, Chau S, Yang J. Spatiotemporal regulation of epithelialmesenchymal transition is essential for squamous cell carcinoma metastasis. Cancer Cell. 2012;22(6):72536. https://doi.org/10.1016/j.ccr.2012.09.022.

84. Trimboli AJ, Fukino $\mathrm{K}$, de Bruin A, Wei G, Shen L, Tanner SM, et al. Direct evidence for epithelial-mesenchymal transitions in breast cancer. Cancer Res. 2008;68(3):937-45. https://doi. org/10.1158/0008-5472.CAN-07-2148.

85. Rhim AD, Mirek ET, Aiello NM, Maitra A, Bailey JM, McAllister F, et al. EMT and dissemination precede pancreatic tumor formation. Cell. 2012;148:349-61. https://doi.org/10.1016/j. cell.2011.11.025.

86. Sarrio D, Rodriguez-Pinilla SM, Hardisson D, Cano A, Moreno-Bueno G, Palacios J. Epithelialmesenchymal transition in breast cancer relates to the basal-like phenotype. Cancer Res.
2008;68(4):989-97. https://doi.org/10.1158/00085472.CAN-07-2017.

87. McCart Reed AE, Kutasovic JR, Vargas AC, Jayanthan J, Al-Murrani A, Reid LE, et al. An epithelial to mesenchymal transition programme does not usually drive the phenotype of invasive lobular carcinomas. J Pathol. 2016;238:489-94. https://doi. org/10.1002/path.4668.

88. Alix-Panabieres C, Mader S, Pantel K. Epithelialmesenchymal plasticity in circulating tumor cells. J Mol Med (Berl). 2017;95(2):133-42. https://doi. org/10.1007/s00109-016-1500-6.

89. Francart ME, Lambert J, Vanwynsberghe AM, Thompson EW, Bourcy M, Polette M, et al. Epithelial-mesenchymal plasticity and circulating tumor cells: travel companions to metastases. Dev Dyn. 2018;247(3):432-50. https://doi.org/10.1002/ dvdy.24506.

90. Zhang Z, Fan W, Deng Q, Tang S, Wang P, Xu P, et al. The prognostic and diagnostic value of circulating tumor cells in bladder cancer and upper tract urothelial carcinoma: a meta- analysis of 30 published studies. Oncotarget. 2017;8:59527-38. https://doi.org/10.18632/oncotarget.18521.

91. Khoo BL, Lee SC, Kumar P, Tan TZ, Warkiani ME, Ow SG, et al. Short-term expansion of breast circulating cancer cells predicts response to anti-cancer therapy. Oncotarget. 2015;6(17):15578-93. https:// doi.org/10.18632/oncotarget.3903.

92. Thiery JP, Lim CT. Tumor dissemination: an EMT affair. Cancer Cell. 2013;23(3):272-3. https://doi. org/10.1016/j.ccr.2013.03.004.

93. Chen Y-Y, Ma L, Gong W-F, Zhong J-H, Han Z-G, Qi L-N, et al. Circulating tumor cells undergoing EMT provide a metric for diagnosis and prognosis of patients with hepatocellular carcinoma. Cancer Res. 2018;78:4731-44. https://doi.org/10.1158/00085472.can-17-2459.

94. Wu S, Liu S, Liu Z, Huang J, Pu X, Li J, et al. Classification of circulating tumor cells by epithelial-mesenchymal transition markers. PLoS ONE. 2015;10:1-14. https://doi.org/10.1371/journal.pone.0123976.

95. Zhao X-H, Wang Z-R, Chen C-L, Di L, Bi Z-F, $\mathrm{Li} \mathrm{Z}-\mathrm{H}$, et al. Molecular detection of epithelialmesenchymal transition markers in circulating tumor cells from pancreatic cancer patients: Potential role in clinical practice. World J Gastroenterol. 2019;25:138-50. https://doi.org/10.3748/wjg.v25. i1.138.

96. Hodara E, Morrison G, Cunha A, Zainfeld D, Xu T, $\mathrm{Xu} \mathrm{Y}$ et al. Multiparametric liquid biopsy analysis in metastatic prostate cancer. JCI Insight. 2019;4(5). https://doi.org/10.1172/jci.insight.125529.

97. Chistiakov DA, Chekhonin VP. Circulating tumor cells and their advances to promote cancer metastasis and relapse, with focus on glioblastoma multiforme. Exp Mol Pathol. 2018;105:166-74. https:// doi.org/10.1016/j.yexmp.2018.07.007. 
98. Aktas B, Tewes M, Fehm T, Hauch S, Kimmig R, Kasimir-Bauer S. Stem cell and epithelialmesenchymal transition markers are frequently overexpressed in circulating tumor cells of metastatic breast cancer patients. Breast Cancer Res. 2009;11(4):R46.

99. Armstrong AJ, Marengo MS, Oltean S, Kemeny G, Bitting RL, Turnbull JD, et al. Circulating tumor cells from patients with advanced prostate and breast cancer display both epithelial and mesenchymal markers. Mol Cancer Res. 2011;9(8):997-1007. https://doi.org/10.1158/1541-7786.MCR-10-0490.

100. Gradilone A, Raimondi C, Nicolazzo C, Petracca A, Gandini O, Vincenzi B, et al. Circulating tumor cells lacking cytokeratin in breast cancer: the importance of being mesenchymal. J Cell Mol Med. 2011;15:1066-70.

101. Kallergi G, Papadaki MA, Politaki E, Mavroudis D, Georgoulias V, Agelaki S. Epithelial to mesenchymal transition markers expressed in circulating tumour cells of early and metastatic breast cancer patients. Breast Cancer Res. 2011;13(3):R59. https://doi.org/10.1186/bcr2896.

102. Markou A, Strati A, Malamos N, Georgoulias V, Lianidou ES. Molecular characterization of circulating tumor cells in breast cancer by a liquid bead array hybridization assay. Clin Chem. 2011;57(3):421-30. https://doi.org/10.1373/clinchem.2010.154328.

103. Raimondi C, Gradilone A, Naso G, Vincenzi B, Petracca A, Nicolazzo C, et al. Epithelialmesenchymal transition and stemness features in circulating tumor cells from breast cancer patients. Breast Cancer Res Treat. 2011;130:449-55.

104. Strati A, Markou A, Parisi C, Politaki E, Mavroudis D, Georgoulias V, et al. Gene expression profile of circulating tumor cells in breast cancer by RT-qPCR. BMC Cancer. 2011;11:422. https://doi. org/10.1186/1471-2407-11-422.

105. Barriere G, Riouallon A, Renaudie J, Tartary M, Rigaud M. Mesenchymal and stemness circulating tumor cells in early breast cancer diagnosis. BMC Cancer. 2012;12:114. https://doi. org/10.1186/1471-2407-12-114.

106. Barriere G, Riouallon A, Renaudie J, Tartary M, Rigaud M. Mesenchymal characterization: alternative to simple CTC detection in two clinical trials. Anticancer Res. 2012;32(8):3363-9.

107. Giordano A, Gao H, Anfossi S, Cohen E, Mego $\mathrm{M}$, Lee $\mathrm{BN}$, et al. Epithelial-mesenchymal transition and stem cell markers in patients with HER2-positive metastatic breast cancer. Mol Cancer Ther. 2012;11(11):2526-34. https://doi. org/10.1158/1535-7163.

108. Kasimir-Bauer S, Hoffmann O, Wallwiener D, Kimmig R, Fehm T. Expression of stem cell and epithelial-mesenchymal transition markers in primary breast cancer patients with circulating tumor cells. Breast Cancer Res. 2012;14(1):R15. https:// doi.org/10.1186/bcr3099.

109. Mego M, Gao H, Lee BN, Cohen EN, Tin S, Giordano A, et al. Prognostic value of EMTcirculating tumor cells in metastatic breast cancer patients undergoing high-dose chemotherapy with autologous hematopoietic stem cell transplantation. J Cancer. 2012;3:369-80. https://doi.org/10.7150/ jca.5111.

110. Mego M, Mani SA, Lee BN, Li C, Evans KW, Cohen $\mathrm{EN}$, et al. Expression of epithelial-mesenchymal transition-inducing transcription factors in primary breast cancer: the effect of neoadjuvant therapy. Int J Cancer. 2012;130(4):808-16. https://doi. org/10.1002/ijc. 26037.

111. Baccelli I, Schneeweiss A, Riethdorf S, Stenzinger A, Schillert A, Vogel V, et al. Identification of a population of blood circulating tumor cells from breast cancer patients that initiates metastasis in a xenograft assay. Nat Biotechnol. 2013;31(6):539-44. https://doi.org/10.1038/nbt.2576.

112. Cierna Z, Mego M, Janega P, Karaba M, Minarik $\mathrm{G}$, Benca $\mathrm{J}$, et al. Matrix metalloproteinase 1 and circulating tumor cells in early breast cancer. BMC Cancer. 2014;14:472. https://doi. org/10.1186/1471-2407-14-472.

113. Markiewicz A, Ksiazkiewicz M, WelnickaJaskiewicz M, Seroczynska B, Skokowski J, Szade $\mathrm{J}$, et al. Mesenchymal phenotype of CTC-enriched blood fraction and lymph node metastasis formation potential. PLoS One. 2014;9(4):e93901. https://doi. org/10.1371/journal.pone.0093901.

114. Markiewicz A, Welnicka-Jaskiewicz M, Seroczynska B, Skokowski J, Majewska H, Szade $\mathrm{J}$, et al. Epithelial-mesenchymal transition markers in lymph node metastases and primary breast tumors - relation to dissemination and proliferation. Am J Transl Res. 2014;6(6):793-808.

115. Papadaki MA, Kallergi G, Zafeiriou Z, Manouras L, Theodoropoulos PA, Mavroudis D, et al. Co-expression of putative stemness and epithelialto-mesenchymal transition markers on single circulating tumour cells from patients with early and metastatic breast cancer. BMC Cancer. 2014;14:651. https://doi.org/10.1186/1471-2407-14-651.

116. Serrano MJ, Ortega FG, Alvarez-Cubero MJ, Nadal R, Sanchez-Rovira P, Salido M, et al. EMT and EGFR in CTCs cytokeratin negative non-metastatic breast cancer. Oncotarget. 2014;5(17):7486-97. https://doi.org/10.18632/oncotarget.2217.

117. Polioudaki H, Agelaki S, Chiotaki R, Politaki E, Mavroudis D, Matikas A, et al. Variable expression levels of keratin and vimentin reveal differential EMT status of circulating tumor cells and correlation with clinical characteristics and outcome of patients with metastatic breast cancer. BMC Cancer. 2015;15:110. https://doi.org/10.1186/s12885-015-1386-7. 
118. Satelli A, Brownlee Z, Mitra A, Meng QH, Li S. Circulating tumor cell enumeration with a combination of epithelial cell adhesion molecule-and cell-surface vimentin-based methods for monitoring breast cancer therapeutic response. Clin Chem. 2015;61:259-66. https://doi.org/10.1373/ clinchem.2014.228122.

119. Ueo H, Sugimachi K, Gorges TM, Bartkowiak K, Yokobori T, Muller V, et al. Circulating tumour cell-derived plastin3 is a novel marker for predicting long-term prognosis in patients with breast cancer. Br J Cancer. 2015;112(9):1519-26. https://doi. org/10.1038/bjc.2015.132.

120. Wang HY, Ahn S, Kim S, Park S, Jung D, Park S, et al. Detection of circulating tumor cell-specific markers in breast cancer patients using the quantitative RT-PCR assay. Int J Clin Oncol. 2015;20(5):878-90. https://doi.org/10.1007/s10147-015-0798-3.

121. Bourcy M, Suarez-Carmona M, Lambert J, Francart ME, Schroeder H, Delierneux C, et al. Tissue factor induced by epithelial-mesenchymal transition triggers a procoagulant state that drives metastasis of circulating tumor cells. Cancer Res. 2016;76(14):4270-82. https://doi.org/10.1158/00085472.can-15-2263.

122. Bulfoni M, Gerratana L, Del Ben F, Marzinotto $\mathrm{S}$, Sorrentino M, Turetta M, et al. In patients with metastatic breast cancer the identification of circulating tumor cells in epithelial-to-mesenchymal transition is associated with a poor prognosis. Breast Cancer Res. 2016;18(1):30. https://doi.org/10.1186/ s13058-016-0687-3.

123. Hensler M, Vancurova I, Becht E, Palata O, Strnad P, Tesarova $\mathrm{P}$, et al. Gene expression profiling of circulating tumor cells and peripheral blood mononuclear cells from breast cancer patients. Oncoimmunology. 2016;5(4):e1102827. https://doi.org/10.1080/21624 $02 x .2015 .1102827$.

124. Hyun KA, Koo GB, Han H, Sohn J, Choi W, Kim SI, et al. Epithelial-to-mesenchymal transition leads to loss of EpCAM and different physical properties in circulating tumor cells from metastatic breast cancer. Oncotarget. 2016;7(17):24677-87. https://doi. org/10.18632/oncotarget.8250.

125. Reijm EA, Sieuwerts AM, Smid M, Vries JB, Mostert B, Onstenk W, et al. An 8-gene mRNA expression profile in circulating tumor cells predicts response to aromatase inhibitors in metastatic breast cancer patients. BMC Cancer. 2016;16:123. https:// doi.org/10.1186/s12885-016-2155-y.

126. Horimoto Y, Tokuda E, Murakami F, Uomori T, Himuro T, Nakai K, et al. Analysis of circulating tumour cell and the epithelial mesenchymal transition (EMT) status during eribulin-based treatment in 22 patients with metastatic breast cancer: a pilot study. J Transl Med. 2018;16(1):287. https://doi. org/10.1186/s12967-018-1663-8.

127. Guan X, Ma F, Li C, Wu S, Hu S, Huang J, et al. The prognostic and therapeutic implications of circulating tumor cell phenotype detection based on epithelial-mesenchymal transition markers in the first-line chemotherapy of HER2-negative metastatic breast cancer. Cancer Commun. 2019;39:1-10. https://doi.org/10.1186/s40880-018-0346-4.

128. Markiewicz A, Topa J, Nagel A, Skokowski J, Seroczynska B, Stokowy $\mathrm{T}$ et al. Spectrum of epithelial-mesenchymal transition phenotypes in circulating tumour cells from early breast cancer patients. Cancer. 2019;11(1). https://doi. org/10.3390/cancers11010059.

129. Pastushenko I, Brisebarre A, Sifrim A, Fioramonti $\mathrm{M}$, Revenco $\mathrm{T}$, Boumahdi $\mathrm{S}$ et al. Identification of the tumour transition states occurring during EMT. Nature. 2018;556. https://doi.org/10.1038/ s41586-018-0040-3.

130. Grigore AD, Jolly MK, Jia D, Farach-Carson MC, Levine H. Tumor budding: the name is EMT. Partial EMT. J Clin Med. 2016;5(5). https://doi.org/10.3390/ jem5050051.

131. Jolly MK, Tripathi SC, Somarelli JA, Hanash SM, Levine H. Epithelial/mesenchymal plasticity: how have quantitative mathematical models helped improve our understanding? Mol Oncol. 2017;11:739-54. https://doi. org/10.1002/1878-0261.12084.

132. Arnoux V, Nassour M, L'Helgoualc'h A, Hipskind RA, Savagner P. Erk5 controls Slug expression and keratinocyte activation during wound healing. Mol Biol Cell. 2008;19(11):4738-49. https://doi. org/10.1091/mbc.E07-10-1078.

133. Blanco MJ, Barrallo-Gimeno A, Acloque $\mathrm{H}$, Reyes AE, Tada M, Allende ML, et al. Snailla and Snaillb cooperate in the anterior migration of the axial mesendoderm in the zebrafish embryo. Development. 2007;134(22):4073-81. https://doi. org/10.1242/dev.006858.

134. Futterman MA, Garcia AJ, Zamir EA. Evidence for partial epithelial-to-mesenchymal transition (pEMT) and recruitment of motile blastoderm edge cells during avian epiboly. Dev Dyn. 2011;240(6):1502-11. https://doi.org/10.1002/dvdy.22607.

135. Grande MT, Sanchez-Laorden B, Lopez-Blau C, De Frutos CA, Boutet A, Arevalo M, et al. Snaill-induced partial epithelial-to-mesenchymal transition drives renal fibrosis in mice and can be targeted to reverse established disease. Nat Med. 2015;21(9):989-97. https://doi.org/10.1038/nm.3901.

136. Leroy P, Mostov KE. Slug is required for cell survival during partial epithelial-mesenchymal transition of HGF-induced tubulogenesis. Mol Biol Cell. 2007;18(5):1943-52. https://doi.org/10.1091/mbc. e06-09-0823.

137. Lovisa S, LeBleu VS, Tampe B, Sugimoto H, Vadnagara K, Carstens JL, et al. Epithelial-tomesenchymal transition induces cell cycle arrest and parenchymal damage in renal fibrosis. Nat Med. 2015;21(9):998-1009. https://doi.org/10.1038/ nm.3902. 
138. van Helvert S, Storm C, Friedl P. Mechanoreciprocity in cell migration. Nat Cell Biol. 2018;20(1):8-20. https://doi.org/10.1038/s41556-017-0012-0.

139. Aceto N, Bardia A, Miyamoto DT, Donaldson MC, Wittner BS, Spencer JA, et al. Circulating tumor cell clusters are oligoclonal precursors of breast cancer metastasis. Cell. 2014;158:1110-22. https://doi. org/10.1016/j.cell.2014.07.013.

140. Au SH, Storey BD, Moore JC, Tang Q, Chen Y-L, Javaid S, et al. Clusters of circulating tumor cells traverse capillary-sized vessels. Proc Natl Acad Sci. 2016;113:4947-52. https://doi.org/10.1073/ pnas. 1524448113

141. Suo Y, Xie C, Zhu X, Fan Z, Yang Z, He H, et al. Proportion of circulating tumor cell clusters increases during cancer metastasis. Cytometry A. 2017;91(3):250-3. https://doi.org/10.1002/ cyto.a.23037.

142. Murlidhar V, Reddy RM, Fouladdel S, Zhao L, Ishikawa MK, Grabauskiene S, et al. Poor prognosis indicated by venous circulating tumor cell clusters in early stage lung cancers. Cancer Res. 2017;77:5194-206. https://doi.org/10.1158/00085472.CAN-16-2072.

143. Au SH, Edd J, Stoddard AE, Wong KHK, Fachin F, Maheswaran S, et al. Microfluidic isolation of circulating tumor cell clusters by size and asymmetry. Sci Rep. 2017;7:2433. https://doi.org/10.1038/ s41598-017-01150-3.

144. Sarioglu AF, Aceto N, Kojic N, Donaldson MC, Zeinali M, Hamza B, et al. A microfluidic device for label-free, physical capture of circulating tumor cell clusters. Nat Methods. 2015;12:685-91. https://doi. org/10.1038/nmeth.3404.

145. Szczerba BM, Castro-Giner F, Vetter M, Krol I, Gkountela S, Landin J, et al. Neutrophils escort circulating tumour cells to enable cell cycle progression. Nature. 2019;566(7745):553-7. https://doi. org/10.1038/s41586-019-0915-y.

146. Gkountela S, Castro-Giner F, Szczerba BM, Vetter M, Landin J, Scherrer R, et al. Circulating tumor cell clustering shapes DNA methylation to enable metastasis seeding. Cell. 2019;176(1-2):98-112 e14. https://doi.org/10.1016/j.cell.2018.11.046.

147. Thiery JP, Acloque H, Huang RYJ, Nieto MA. Epithelial-mesenchymal transitions in development and disease. Cell. 2009;139:871-90. https:// doi.org/10.1016/j.cell.2009.11.007.

148. Labelle M, Begum S, Hynes Richard O. Direct signaling between platelets and cancer cells induces an epithelial-mesenchymal-like transition and promotes metastasis. Cancer Cell. 2011;20:576-90. https://doi.org/10.1016/j.ccr.2011.09.009.

149. Cheung KJ, Ewald AJ. A collective route to metastasis: seeding by tumor cell clusters. Science (New York, NY). 2016;352:167-9. https://doi. org/10.1126/science.aaf6546.

150. Friedl P, Gilmour D. Collective cell migration in morphogenesis, regeneration and cancer. Nat
Rev Mol Cell Biol. 2009;10:445-57. https://doi. org/10.1038/nrm2720.

151. Cheung KJ, Padmanaban V, Silvestri V, Schipper K, Cohen JD, Fairchild AN, et al. Polyclonal breast cancer metastases arise from collective dissemination of keratin 14-expressing tumor cell clusters. Proc Natl Acad Sci U S A. 2016;113(7):E854-63. https://doi.org/10.1073/pnas.1508541113.

152. Collisson EA, Sadanandam A, Olson P, Gibb WJ, Truitt M, Gu S, et al. Subtypes of pancreatic ductal adenocarcinoma and their differing responses to therapy. Nat Med. 2011;17(4):500-3. https://doi. org/10.1038/nm.2344.

153. Bailey P, Chang DK, Nones K, Johns AL, Patch AM, Gingras MC, et al. Genomic analyses identify molecular subtypes of pancreatic cancer. Nature. 2016;531(7592):47-52. https://doi.org/10.1038/ nature 16965.

154. Moffitt RA, Marayati R, Flate EL, Volmar KE, Loeza SG, Hoadley KA, et al. Virtual microdissection identifies distinct tumor- and stroma-specific subtypes of pancreatic ductal adenocarcinoma. Nat Genet. 2015;47(10):1168-78. https://doi.org/10.1038/ ng.3398.

155. Mitra A, Mishra L, Li S. EMT, CTCs and CSCs in tumor relapse and drug-resistance. Oncotarget 2015;6. https://doi.org/10.18632/oncotarget.4037.

156. Tan TZ, Miow QH, Miki Y, Noda T, Mori S, Huang RY, et al. Epithelial-mesenchymal transition spectrum quantification and its efficacy in deciphering survival and drug responses of cancer patients. EMBO Mol Med. 2014;6(10):1279-93. https://doi. org/10.15252/emmm.201404208.

157. Tiwari N, Gheldof A, Tatari M, Christofori G. EMT as the ultimate survival mechanism of cancer cells. Semin Cancer Biol. 2012;22(3):194-207. https:// doi.org/10.1016/j.semcancer.2012.02.013.

158. Frisch SM, Schaller M, Cieply B. Mechanisms that link the oncogenic epithelial-mesenchymal transition to suppression of anoikis. J Cell Sci. 2013;126(Pt 1):21-9. https://doi.org/10.1242/jcs.120907.

159. Krawczyk N, Hartkopf A, Banys M, Meier-Stiegen F, Staebler A, Wallwiener M, et al. Prognostic relevance of induced and spontaneous apoptosis of disseminated tumor cells in primary breast cancer patients. BMC Cancer. 2014;14:394. https://doi. org/10.1186/1471-2407-14-394.

160. Chebouti I, Kasimir-Bauer S, Buderath P, Wimberger P, Hauch S, Kimmig R, et al. EMT-like circulating tumor cells in ovarian cancer patients are enriched by platinum-based chemotherapy. Oncotarget. 2017;5:48820-31. https://doi.org/10.18632/ oncotarget.16179.

161. Yokobori $T$, Inuma $H$, Shimamura $T$, Imoto $S$, Sugimachi K, Ishii $\mathrm{H}$, et al. Plastin3 is a novel marker for circulating tumor cells undergoing the epithelial-mesenchymal transition and is associated with colorectal cancer prognosis. Cancer Res. 2013;73(7):2059-69. https://doi.org/10.1158/00085472.CAN-12-0326. 
162. Karabacak NM, Spuhler PS, Fachin F, Lim EJ, Pai V, Ozkumur E, et al. Microfluidic, marker-free isolation of circulating tumor cells from blood samples. Nat Protoc. 2014;9(3):694-710. https://doi.org/10.1038/ nprot.2014.044.

163. Ge F, Zhang H, Wang DD, Li L, Lin PP. Enhanced detection and comprehensive in situ phenotypic characterization of circulating and disseminated heteroploid epithelial and glioma tumor cells. Oncotarget. 2015;6(29):27049-64. https://doi.org/10.18632/ oncotarget. 4819 .

164. Naume B, Borgen E, Tossvik S, Pavlak N, Oates D, Nesland JM. Detection of isolated tumor cells in peripheral blood and in BM: evaluation of a new enrichment method. Cytotherapy. 2004;6(3):24452. https://doi.org/10.1080/14653240410006086.

165. Wang ZP, Eisenberger MA, Carducci MA, Partin AW, Scher HI, Ts'o PO. Identification and characterization of circulating prostate carcinoma cells. Cancer. 2000;88(12):2787-95.

166. Hosokawa M, Kenmotsu H, Koh Y, Yoshino T, Yoshikawa T, Naito T et al. Size-based isolation of circulating tumor cells in lung cancer patients using a microcavity array system. PLoS ONE. 2013;8. https://doi.org/10.1371/journal.pone.0067466.

167. Kim T-H, Lim M, Park J, Oh JM, Kim H, Jeong H, et al. FAST: size-selective, clog-free isolation of rare cancer cells from whole blood at a liquid-liquid interface. Anal Chem. 2017;89:1155-62. https://doi. org/10.1021/acs.analchem.6b03534.

168. Hayashi M, Zhu P, McCarty G, Meyer CF, Pratilas CA, Levin A, et al. Size-based detection of sarcoma circulating tumor cells and cell clusters. Oncotarget. 2017;8(45):78965-77. https://doi.org/10.18632/ oncotarget.20697.

169. Rosenberg R, Gertler R, Friederichs J, Fuehrer K, Dahm M, Phelps R, et al. Comparison of two density gradient centrifugation systems for the enrichment of disseminated tumor cells in blood. Cytometry. 2002;49:150-8. https://doi.org/10.1002/cyto.10161.

170. Hou JM, Krebs M, Ward T, Sloane R, Priest L, Hughes A, et al. Circulating tumor cells as a window on metastasis biology in lung cancer. Am J Pathol. 2011;178(3):989-96. https://doi.org/10.1016/j. ajpath.2010.12.003.

171. Gogoi P, Sepehri S, Zhou Y, Gorin MA, Paolillo C, Capoluongo E, et al. Development of an automated and sensitive microfluidic device for capturing and characterizing circulating tumor cells (CTCs) from clinical blood samples. PLoS One. 2016;11:e0147400. https://doi.org/10.1371/journal. pone. 0147400 .

172. Kim YJ, Kang YT, Cho YH. Poly(ethylene glycol)modified tapered-slit membrane filter for efficient release of captured viable circulating tumor cells. Anal Chem. 2016;88:7938-45. https://doi. org/10.1021/acs.analchem.5b04927.

173. Friedlander TW, Premasekharan G, Paris PL. Looking back, to the future of circulating tumor cells. Pharmacol Ther. 2014;142(3):271-80. https:// doi.org/10.1016/j.pharmthera.2013.12.011.

174. Chen L, Peng M, Li N, Song Q, Yao Y, Xu B, et al. Combined use of EpCAM and FR $\alpha$ enables the high-efficiency capture of circulating tumor cells in non- small cell lung cancer. Sci Rep. 2018:1-10. https://doi.org/10.1038/s41598-018-19391-1.

175. Cho EH, Wendel M, Luttgen M, Yoshioka C, Marrinucci D, Lazar D, et al. Characterization of circulating tumor cell aggregates identified in patients with epithelial tumors. Phys Biol. 2012;9(1):016001. https://doi.org/10.1088/1478-3975/9/1/016001.

176. Marrinucci D, Bethel K, Kolatkar A, Luttgen MS, Malchiodi M, Baehring F, et al. Fluid biopsy in patients with metastatic prostate, pancreatic and breast cancers. Phys Biol. 2012;9(1):016003. https:// doi.org/10.1088/1478-3975/9/1/016003.

177. Kuhn P, Bruce RH, Ladanyi A, Lerner RA, Hsieh $\mathrm{HB}$, Curry DN, et al. A rare-cell detector for cancer. Proc Natl Acad Sci. 2004;101:10501-4. https://doi. org/10.1073/pnas.0404036101.

178. Nagrath S, Sequist LV, Maheswaran S, Bell DW, Irimia D, Ulkus L, et al. Isolation of rare circulating tumour cells in cancer patients by microchip technology. Nature. 2007;450:1235-9. https://doi. org/10.1038/nature06385.

179. Stott SL, Lee RJ, Nagrath S, Yu M, Miyamoto DT, Ulkus L, et al. Isolation and characterization of circulating tumor cells from patients with localized and metastatic prostate. Cancer. 2010;2:25ra23.

180. Zhao M, Wei B, Chiu DT. Imaging multiple biomarkers in captured rare cells by sequential immunostaining and photobleaching. Methods. 2013;64(2):108-13. https://doi.org/10.1016/j. ymeth.2013.08.006.

181. Murlidhar V, Zeinali M, Grabauskiene S, GhannadRezaie M, Wicha MS, Simeone DM, et al. A radial flow microfluidic device for ultra-high-throughput affinity-based isolation of circulating tumor cells. Small. 2014;10(23):4895-904. https://doi. org/10.1002/smll.201400719.

182. Magbanua MJM, Carey LA, DeLuca A, Hwang J, Scott JH, Rimawi MF, et al. Circulating tumor cell analysis in metastatic triple-negative breast cancers. Clin Cancer Res. 2015;21:1098-105. https://doi. org/10.1158/1078-0432.CCR-14-1948.

183. Kim MS, Sim TS, Kim YJ, Kim SS, Jeong H, Park J-M, et al. SSA-MOA: a novel CTC isolation platform using selective size amplification (SSA) and a multi-obstacle architecture (MOA) filter. Lab Chip. 2012;12:2874. https://doi.org/10.1039/c2lc40065k.

184. Harouaka RA, Zhou MD, Yeh YT, Khan WJ, Das A, Liu X, et al. Flexible micro spring array device for high-throughput enrichment of viable circulating tumor cells. Clin Chem. 2014;60(2):323-33. https:// doi.org/10.1373/clinchem.2013.206805.

185. Cabel L, Proudhon C, Gortais H, Loirat D, Coussy F, Pierga JY, et al. Circulating tumor cells: clinical validity and utility. Int J Clin Oncol. 2017;22(3):42130. https://doi.org/10.1007/s10147-017-1105-2. 
186. Patel V, Keating MJ, Wierda WG, Gandhi V. Preclinical combination of TP-0903, an AXL inhibitor and B-PAC-1, a procaspase-activating compound with ibrutinib in chronic lymphocytic leukemia. Leuk Lymphoma. 2016;57:1494-7. https://doi. org/10.3109/10428194.2015.1102243.

187. Giannelli G, Villa E, Lahn M. Transforming growth factor-beta as a therapeutic target in hepatocellular carcinoma. Cancer Res. 2014;74(7):1890-4. https:// doi.org/10.1158/0008-5472.CAN-14-0243.

188. Rodon J, Carducci M, Sepulveda-Sanchez JM, Azaro A, Calvo E, Seoane J, et al. Pharmacokinetic, pharmacodynamic and biomarker evaluation of transforming growth factor-beta receptor I kinase inhibitor, galunisertib, in phase 1 study in patients with advanced cancer. Investig New Drugs. 2015;33(2):357-70. https://doi.org/10.1007/ s10637-014-0192-4.

189. Puls LN, Eadens M, Messersmith W. Current status of SRC inhibitors in solid tumor malignancies. Oncologist. 2011;16(5):566-78. https://doi. org/10.1634/theoncologist.2010-0408.

190. Hospital ZPPs. Aspirin on CTCs of advanced breast and colorectal cancer. 2015. https://ClinicalTrials. gov/show/NCT02602938

191. Biotherapeutics A. Phase I dose escalation study of AB-16B5 in subjects with an advanced solid malignancy. 2015. https://ClinicalTrials.gov/show/ NCT02412462

192. Tolero Pharmaceuticals I. First-in-human study of oral TP-0903 (a Novel Inhibitor of AXL Kinase) in patients with advanced solid tumors. 2016. https:// ClinicalTrials.gov/show/NCT02729298.

193. Alderton GK. Metastasis: epithelial to mesenchymal and back again. Nat Rev Cancer. 2013;13(1):3. https://doi.org/10.1038/nrc3428.

194. Brabletz T. To differentiate or not - routes towards metastasis. Nat Rev Cancer. 2012;12:425-36. https://doi.org/10.1038/nrc3265.

195. Beerling E, Seinstra D, de Wit E, Kester L, van der Velden D, Maynard C, et al. Plasticity between epithelial and mesenchymal states unlinks EMT from metastasis-enhancing stem cell capacity. Cell Rep. 2016;14(10):2281-8. https://doi.org/10.1016/j. celrep.2016.02.034.

196. Nieto MA. Epithelial plasticity: a common theme in embryonic and cancer cells. Science. 2013;342(6159):1234850. https://doi.org/10.1126/ science. 1234850 .

197. Maheswaran S, Haber DA. Ex vivo culture of CTCs: an emerging resource to guide cancer therapy. Cancer Res. 2015;75:2411-6. https://doi.org/10.1158/00085472.CAN-15-0145. 